\title{
$\alpha 6 \beta 1$ and $\alpha 7 \beta 1$ Integrins Are Required in Schwann Cells to Sort Axons
}

\author{
Marta Pellegatta, $, 1,2$ Adèle De Arcangelis, ${ }^{3}$ Alessandra D’Urso, ${ }^{1}$ Alessandro Nodari, ${ }^{1}$ Desirée Zambroni, ${ }^{1}$ \\ Monica Ghidinelli, ${ }^{1,2}$ Vittoria Matafora, ${ }^{1}$ Courtney Williamson, ${ }^{2}$ Elisabeth Georges-Labouesse,${ }^{3 \dagger}$ Jordan Kreidberg, ${ }^{4}$ \\ Ulrike Mayer, ${ }^{5}$ Karen K. McKee, ${ }^{6}$ Peter D. Yurchenco, ${ }^{6}$ Angelo Quattrini, ${ }^{1}$ Lawrence Wrabetz, ${ }^{1,2}$ \\ and Maria Laura Feltri ${ }^{1,2}$ \\ ${ }^{1}$ San Raffaele Scientific Institute, Milano 20132, Italy, ${ }^{2}$ Hunter James Kelly Research Institute, University at Buffalo, State University of New York, New York \\ 14203, 3'Development and Stem Cells Program, Institut de Génétique et de Biologie Moléculaire et Cellulaire, Centre National de la Recherche Scientifique, \\ Unité Mixte de Recherche 7104, Institut National de la Santé et de la Recherche Médicale U964, Université de Strasbourg, Illkirch 67404, France, \\ ${ }^{4}$ Department of Medicine, Children's Hospital Boston and Department of Pediatrics, Harvard Medical School, Boston, Massachusetts 02115, ${ }^{5}$ Biomedical \\ Research Centre, School of Biological Sciences, University of East Anglia, Norwich NR4 7TJ, United Kingdom, and ${ }^{\circ}$ Robert Wood Johnson Medical School, \\ Piscataway, New Jersey, New Jersey 08854
}

During development, Schwann cells extend lamellipodia-like processes to segregate large- and small-caliber axons during the process of radial sorting. Radial sorting is a prerequisite for myelination and is arrested in human neuropathies because of laminin deficiency. Experiments in mice using targeted mutagenesis have confirmed that laminins 211,411 , and receptors containing the $\beta 1$ integrin subunit are required for radial sorting; however, which of the $11 \alpha$ integrins that can pair with $\beta 1$ forms the functional receptor is unknown. Here we conditionally deleted all the $\alpha$ subunits that form predominant laminin-binding $\beta 1$ integrins in Schwann cells and show that only $\alpha 6 \beta 1$ and $\alpha 7 \beta 1$ integrins are required and that $\alpha 7 \beta 1$ compensates for the absence of $\alpha 6 \beta 1$ during development. The absence of either $\alpha 7 \beta 1$ or $\alpha 6 \beta 1$ integrin impairs the ability of Schwann cells to spread and to bind laminin 211 or 411 , potentially explaining the failure to extend cytoplasmic processes around axons to sort them. However, double $\alpha 6 / \alpha 7$ integrin mutants show only a subset of the abnormalities found in mutants lacking all $\beta 1$ integrins, and a milder phenotype. Double-mutant Schwann cells can properly activate all the major signaling pathways associated with radial sorting and show normal Schwann cell proliferation and survival. Thus, $\alpha 6 \beta 1$ and $\alpha 7 \beta 1$ are the laminin-binding integrins required for axonal sorting, but other Schwann cell $\beta 1$ integrins, possibly those that do not bind laminins, may also contribute to radial sorting during peripheral nerve development.

\section{Introduction}

Schwann cells synthesize extensive spiraling membranes containing specific proteins and lipids to generate myelin, which safeguards axons and ensures fast conduction of action potentials.

\footnotetext{
Received July 18, 2013; revised 0ct. 3, 2013; accepted 0ct. 5, 2013.

Author contributions: M.P., L.W., and M.L.F. designed research; M.P., A. D'Urso, A.N., D.Z., M.G., V.M., C.W., K.K.M., and A.Q. performed research; A. De Arcangelis, E.G.-L., J.K., U.M., K.K.M., and P.D.Y. contributed unpublished reagents/analytic tools; M.P., D.Z., P.D.Y., A.Q., L.W., and M.L.F. analyzed data; M.P. and M.L.F. wrote the paper.

This work was supported by National Institute of Neurological Disorders and Stroke R01NS045630 to M.L.F., R01NS055256 to L.W., and R01DK36425 to P.D.Y., Telethon Italia (GPP10007A to M.L.F. and GG10007C to L.W.), and the European Community's Seventh Framework Programme (FP7/2007-2013) HEALTH-F2-2008-201535, UE-FP7 (NGIDD). We thank Guido Tarone (University of Torino), Michael DiPersio (Albany Medical College), Arnoud Sonnenberg (The Netherlands Cancer Institute), Lydia Sorokin (University of Münster), and Virginia Lee (University of Pennsylvania) for antibodies; Angela Bachi (San Raffaele Scientific Institute) for useful suggestions and access to the proteomic facility; and Nilo Riva (San Raffaele Hospital) for help with morphometry.

This work would not have been possible without the contribution of Elisabeth Georges-Labouesse who provided $\alpha 6$-floxed mice. Sadly, Elisabeth passed away prematurely on July 21, 2012.

The authors declare no competing financial interests.

${ }^{\dagger}$ Deceased July 21, 2012.

Correspondence should be addressed to Dr. Maria Laura Feltri, Hunter James Kelly Research Institute, State University of New York at Buffalo, Department of Biochemistry \& Neurology, School of Medicine and Biomedical Sciences, New York Center of Excellence in Bioinformatics \& Life Sciences, 701 Ellicott Street, B4-322, Buffalo, NY 14203. E-mail: mlfeltri@buffalo.edu.

DOI:10.1523/JNEUROSCI.3179-13.2013

Copyright $\odot 2013$ the authors $\quad 0270-6474 / 13 / 3317995-13 \$ 15.00 / 0$
}

Before myelination, Schwann cells engage in a 1:1 relationship with large-caliber axons, which they achieve during a multistep process called radial sorting (Webster et al., 1973). Before radial sorting, Schwann cells deposit a basal lamina, which contain laminins. Laminins are trimeric glycoproteins in which different $\alpha$-, $\beta$-, and $\gamma$ - subunits combine with remarkable tissue specificity (Miner and Yurchenco, 2004). The basal lamina of Schwann cells contains laminin $211(\alpha 2 \beta 1 \gamma 1), 411(\alpha 4 \beta 1 \gamma 1)$, and 511 $(\alpha 5 \beta 1 \gamma 1)$; laminin 511 is specifically localized around nodes of Ranvier (Occhi et al., 2005). Laminins 211 and 411 have both redundant and specific functions in axonal sorting. Mutations in the $\alpha 2$ chain of laminin 211 cause congenital muscular dystrophy 1A (CMD1A), which includes a muscular dystrophy, a peripheral neuropathy, and central nervous system abnormalities (HelblingLeclerc et al., 1995). The peripheral neuropathy has been studied mostly in the dystrophic $(d y / d y)$ mutant mice and is characterized by a partial arrest in radial sorting (for review, see Feltri and Wrabetz, 2005). Similarly, laminin $\alpha 4$ (411) deficient mice have modest impairment in radial sorting (Wallquist et al., 2005; Yang et al., 2005). However, axonal sorting is entirely arrested in combined $\alpha 2 / \alpha 4$ double laminin mutants, with axons remaining naked and amyelinated (Yang et al., 2005; Yu et al., 2005). This 
synergistic interaction between laminins 211 and 411 suggests distinct roles, which could be explained by specific interactions with dedicated receptors. Schwann cells express integrins and dystroglycan laminin receptors. Deletion of the $\beta 1$ integrin subunit in Schwann cells almost completely arrests sorting (Feltri et al., 2002), and deletion of $\beta 1$ integrins and dystroglycan in Schwann cells completely impairs the process (Berti et al., 2011). $\beta 1$ integrins are heterodimers formed by one of 11 possible $\alpha$ subunits that combine with the $\beta 1$ chain to form dimers with various ligand specificities. Which $\beta 1$ dimer is required for radial sorting in Schwann cells is unknown. Because the abnormalities resulting from deletion of $\beta 1$ integrin resemble those resulting from deletion of laminins, we focused on the $\alpha \beta 1$ integrins that bind laminins. Schwann cells in vivo express three $\beta 1$ integrins that are structurally similar (do not contain the $\alpha \mathrm{I}$ domain) and are mainly laminin receptors $(\alpha 3 \beta 1, \alpha 6 \beta 1$, and $\alpha 7 \beta 1)$, and two $\alpha \mathrm{I}$-containing, hybrid integrins $(\alpha 1 \beta 1, \alpha 2 \beta 1)$, which also bind collagen (Previtali et al., 2003a, b). Whether these receptors are used interchangeably and are redundant or they have unique ligand specificities and functions in Schwann cells and other cell types is largely unknown. Here we show that $\alpha 6 \beta 1$ and $\alpha 7 \beta 1$ are required for radial sorting. Deletion of $\alpha 6 \beta 1$ or $\alpha 7 \beta 1$ integrins causes different effects on Schwann cell development and on their ability to bind laminins 211 and 411 , suggesting specific roles for laminin-integrin receptor pairs in Schwann cells.

\section{Materials and Methods}

Transgenic mice. All experiments involving animals followed experimental protocols approved by the San Raffaele Scientific Institute and Roswell Park Cancer Institute Animal Care and Use Committees. $\alpha 6$ integrin "floxed" $\left.{ }^{F}\right)$ mice will be described (A. De Arcangelis et al., manuscript in preparation); $\alpha 7$ integrin knock-out and $\alpha 3$ integrin floxed mice have been described (Mayer et al., 1997; Liu et al., 2009). $\alpha 6$ integrin constitutive heterozygous null mice were the progeny of animals obtained by crossing $\alpha 6$ integrin $^{\mathrm{F} /+}$ animals and CMV-Cre animal. P0Cre transgenic mice have been previously characterized (Feltri et al., 1999, 2002). $\alpha 6$ integrin $^{F / F}, \alpha 6^{-1-}$, and $\alpha 7$ integrin $^{-1-}$ mice were congenic in C57BL/6 background. $\alpha 3$ integrin floxed mice were in a 129Sv/B6 mixed background; the progeny in this study resulted from parents that were N3-N4 generations congenic for C57BL6. Double $\alpha 6 / \alpha 7$ integrin mutant mice were derived from parents that were $\mathrm{N} 8$ generations congenic for C57BL6. In the case of non-congenic genetic background, only littermates were compared. Mice of either sex were used. Genotyping of mutant mice was performed by PCR on tail genomic DNA, as described previously (Feltri et al., 1999, 2002; Liu et al., 2009; Germain et al., 2010).

Extraction of genomic DNA from sciatic nerves. Sciatic nerves were dissected from P1 and P28 WT and $\alpha 6$ integrin mutant mice. The perineurium was dissected away, and the nerves were digested overnight at $55^{\circ} \mathrm{C}$ in $500 \mu \mathrm{l}$ SNET (Tris, pH 8.0, $20 \mathrm{~mm}$, EDTA, pH 8.0, $5 \mathrm{~mm}, \mathrm{NaCl} 0.4 \mathrm{M}$, SDS $1 \%$ in distilled water) and $10 \mu \mathrm{l}$ of Proteinase $\mathrm{K}(20 \mathrm{mg} / \mathrm{ml})$. The following day, genomic DNA extraction with phenol/chloroform and PCR analysis was performed.

Mouse DRG explant cultures. Explants were dissected from E13.5 embryos generated by mating $\alpha 6$ integrin $^{+/-}$or $\alpha 7$ integrin $^{+/-}$mice, plated onto rat collagen-I (Cultrex) coated glass coverslips, and maintained for 1 week in NB medium (B27 supplement, D-glucose $4 \mathrm{~g} / \mathrm{L}$, L-glutamine $2 \mathrm{~mm}$, NGF $50 \mathrm{ng} / \mathrm{ml}$ in Neurobasal medium; Invitrogen); myelination was induced for $10 \mathrm{~d}$ with ascorbic acid $(50 \mu \mathrm{g} / \mathrm{ml})$ in C-medium (FCS 10\%, L-glutamine $2 \mathrm{~mm}$, D-glucose $4 \mathrm{~g} / \mathrm{L}, \mathrm{NGF} 50 \mathrm{ng} / \mathrm{ml}$ in MEM; Invitrogen). Explants were then fixed in $4 \%$ PFA for $20^{\prime}$ or nonfixed, washed, permeabilized with cold methanol for $5^{\prime}$, and stained according to standard immunohistochemistry protocols. For myelin internode quantification, the number of MBP-positive internodes in 10-15 images taken for each DRG was counted. This analysis was per- formed on at least three coverslips per embryo and on three embryos per genotype.

RNA extraction and semiquantitative RT-PCR analysis. Sciatic nerves from P5 wild-type and $\alpha 6$ mutant mice were frozen in liquid nitrogen. Total RNA was prepared with TRIzol (Roche Diagnostic), and $1 \mu \mathrm{g}$ of RNA was reverse transcribed using $1 \mathrm{~mm}$ dNTPs, $2.5 \mathrm{ng} / \mathrm{ml}$ random examers, 40 units Rnasin, and SuperScriptII RNase H-Reverse Transcriptase (Invitrogen) as per the manufacturer's instructions.

TaqMan quantitative PCR analysis. Total RNA $(1 \mu \mathrm{g})$ was retrotranscribed, and quantitative PCR was performed according to manufacturer's instructions (TaqMan, PE Applied Biosystems) on an ABI PRISM 7700 sequence detection system (Applied Biosystems). The relative standard curve method was applied using wild-type mice as reference. Normalization was performed using $18 \mathrm{~S}$ rRNA as a reference gene. Target and reference gene PCR amplification was performed in separate tubes with Assays on Demand (Applied Biosystems): 18S assay: Hs99999901_s1; and $\alpha 7$ integrin assay: Mm 00434400_m1.

Western blotting and Racl assay. Frozen sciatic nerves dissected from $\mathrm{P} 1, \mathrm{P}$, and P28 mice were pulverized, sonicated in lysis buffer $(95 \mathrm{~mm}$ $\mathrm{NaCl}, 25$ mм Tris-HCl, pH 7.4, 10 mм EDTA, 2\% SDS, 1 mm Na $\mathrm{VO}_{4}, 1$ $\mathrm{mm} \mathrm{NaF}$ ), and 1:100 Protease Inhibitor Cocktail (Sigma-Aldrich), boiled for $5 \mathrm{~min}$, and centrifuged at $14,000 \times \mathrm{rpm}$ in a microcentrifuge for 10 $\min$ at $16^{\circ} \mathrm{C}$ to eliminate insoluble material. The protein concentration in supernatants was determined by BCA protein assay (Thermo Scientific) according to the manufacturer's instructions. DRG explants were rinsed three times in PBS on ice and then suspended in lysis buffer $(95 \mathrm{~mm} \mathrm{NaCl}$, 25 mм Tris-HCl, pH 7.4, 10 mм EDTA, 2\% SDS, $1 \mathrm{~mm} \mathrm{Na}_{3} \mathrm{VO}_{4}, 1 \mathrm{~mm}$ $\mathrm{NaF}$, and 1:100 Protease Inhibitor Cocktail; Sigma-Aldrich). After lysis, samples were sonicated in a water sonicator with two cycles of $20 \mathrm{~s}$ at maximum power. Equal amounts of homogenates were loaded with standard reducing or nonreducing sample buffer. The samples were denatured, resolved on SDS-polyacrylamide gel, and electroblotted onto PVDF membrane. To verify equal loading of protein, membranes were stained with Ponceau red. Blots were then blocked with 5\% dry milk in PBS $1 \times 0.1 \%$ Tween or BSA $5 \%$ in PBS $1 \times 0.1 \%$ Tween and incubated with the appropriate antibody. Blots were developed with ECL or ECL plus (GE Healthcare), and band intensity was quantified from the films using ImageJ software. GST pull-down assay for Rac1-GTP was performed as described previously (Nodari et al., 2007).

Immunoprecipitation. Sciatic nerves from wild-type and $\alpha 6$ mutant mice were dissected and sonicated in lysis buffer $(150 \mathrm{~mm} \mathrm{NaCl}, 50 \mathrm{~mm}$ Tris-HCl, pH 7.4, 1 mм EDTA, 1 mм EGTA, 1 mм Na $\mathrm{VO}_{4}, 1$ mм NaF, 1:100 Protease Inhibitor Cocktail [Sigma-Aldrich], 1\% NP-40, $0.25 \%$ sodium deoxycholate, and $0.1 \%$ SDS). After lysis, sciatic nerve extracts were incubated with hamster anti- $\beta 1$ integrin antibodies (BD Biosciences) $\mathrm{O} / \mathrm{N}$ at $4^{\circ} \mathrm{C}$ on a rotating wheel. The following day, they were incubated with protein G-agarose (Sigma) for $1 \mathrm{~h}$ at $4^{\circ} \mathrm{C}$. After washing with lysis buffer with or without detergents, beads were suspended in a solution 1:1 lysis buffer: standard sample buffer $2 \times$ (with $\beta$-mercaptoethanol), and followed by Western blotting.

Mass spectrometry analysis. After immunoprecipitation, samples were loaded and resolved by 7.5\% SDS-PAGE. The gel was then stained with a silver stain mass spectrometry kit (Pierce, as per the manufacturer's instruction). Subsequently, mass spectrometry analysis was performed on discrete isolated bands from the silver-stained gel. Briefly, bands of interest were excised from gel, subjected to reduction by $10 \mathrm{~mm}$ dithiothreitol and alkylation by $55 \mathrm{~mm}$ iodoacetamide, and digested overnight with trypsin (Roche). Supernatant mixtures from the digestion $(10 \mu \mathrm{l})$ were acidified with formic acid up to a final concentration of $10 \%(\mathrm{v} / \mathrm{v})$, desalted and concentrated with Stage Tip $\mu \mathrm{C} 18$ (Proxeon Biosystems), and then separated on a NanoLC (EasyLC, Proxeon Biosystems). Peptide separation occurred on a homemade reverse-phase $15 \mathrm{~cm}$ spraying fused silica capillary column (75 mm i.d.), packed in house with $3 \mathrm{~mm}$ ReproSil-Pur 120C18-AQ (Dr. Maisch). A gradient of eluents $\mathrm{A}\left(\mathrm{H}_{2} \mathrm{O}\right.$ with $2 \% \mathrm{v} / \mathrm{v}$ acetonitrile, $0.5 \% \mathrm{v} / \mathrm{v}$ acetic acid) and $\mathrm{B}(80 \%$ acetonitrile with $0.5 \% \mathrm{v} / \mathrm{v}$ acetic acid) was used to achieve separation, from $7 \% \mathrm{~B}$ (at $0 \mathrm{~min} 0.2 \mu \mathrm{L} / \mathrm{min}$ flow rate) to $40 \% \mathrm{~B}$ (in $60 \mathrm{~min}$, at $0.2 \mu \mathrm{L} / \mathrm{min}$ flow rate). The LC system was connected to an LTQ-Orbitrap mass spectrometer (Thermo Fisher Scientific) equipped with a nanoelectrospray ion 
A

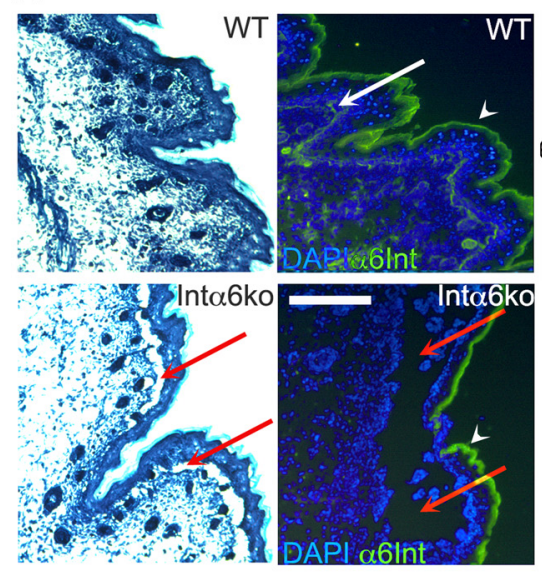

D
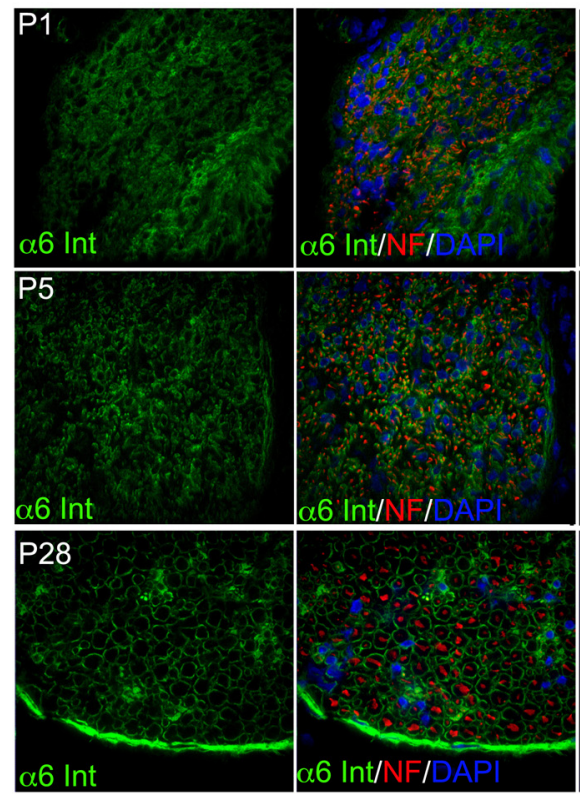

B

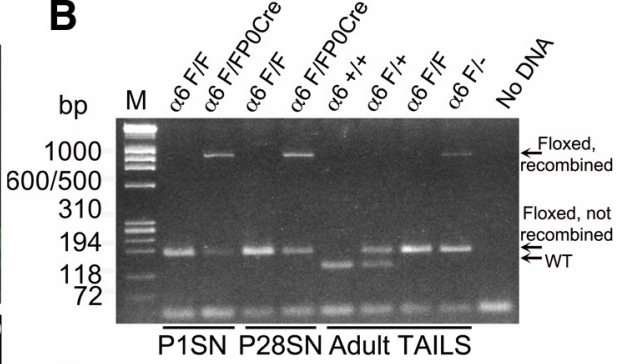

C

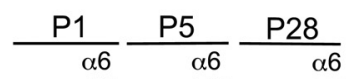

$120 \mathrm{KDa}$ WT CKO WT cKO WT cKO

$55 \mathrm{KDa}$

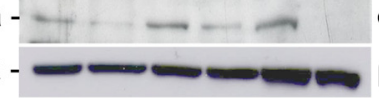

$\alpha 6$ Int $\beta$-tub

$\alpha 6 \mathrm{cKO}$
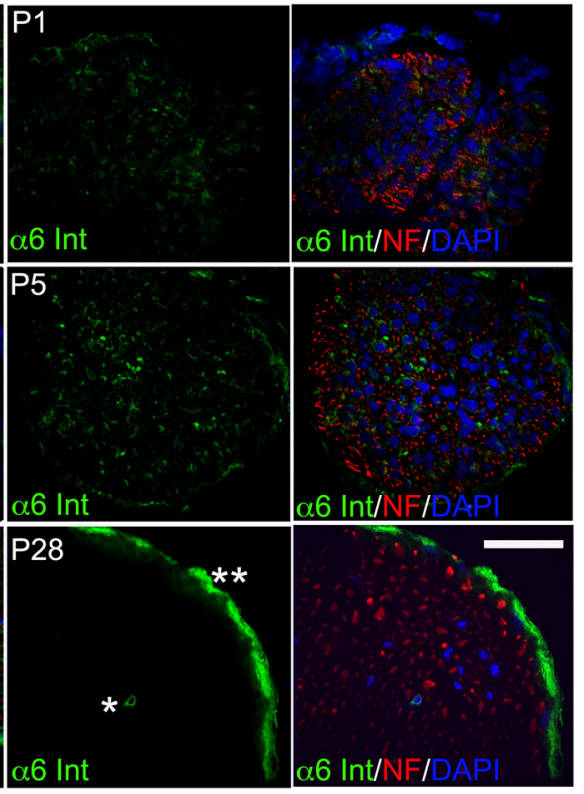

Figure 1. Efficient genomic recombination and Schwann cell-specific deletion of $\alpha 6$ integrin in $\alpha 6$ integrin ${ }^{\mathrm{F} / \mathrm{F}} \mathrm{POCre} \mathrm{mutant}$ nerves. $A$, Constitutive deletion of the $\alpha 6$ allele in $\alpha 6^{-1-}$ mice causes detachment between epidermis and dermis (epidermolysis bullosa) resulting from the absence of $\alpha 6$ integrin (red arrows). The white arrow in wild-type indicates the normal $\alpha 6$ staining at the dermal- epidermal junction. Arrowheads point to a non-specific staining in the stratum corneus. $B$, Genomic DNA from tail samples of wild-type $\left(\alpha 6^{+/+}\right), \alpha 6^{F /+}, \alpha 6^{F / F}$, and $\alpha 6^{F /-}$ mice were amplified using primers AH065 (placed upstream of the $5^{\prime}$ loxP site), AHM4 and AHM3 (flanking the $3^{\prime}$ loxP site) and generated the expected WT (120 base pairs), unrecombined floxed (154 base pair), and recombined floxed (1000 base pair) bands. PCR on genomic DNA from $\alpha 6$ integrin $^{\mathrm{F} / \mathrm{F}}$ and $\alpha 6$ integrin $^{\mathrm{F} / \mathrm{F}} \mathrm{POCre}$ sciatic nerves $(\mathrm{SN})$ at $\mathrm{P} 1$ and $\mathrm{P} 28$ amplified the floxed band and the recombined floxed band only in the presence of POCre at $\mathrm{P} 1$ and $\mathrm{P} 28$. C, D, Western blotting and immunohistochemistry in $\alpha 6$ integrin $^{\mathrm{F} / \mathrm{F}} \mathrm{POCre}{ }^{+/-}$and control sciatic nerves at P1, P5, and P28. $\alpha 6$ integrin is absent in mutant nerves at P28 and markedly reduced by P1. One representative experiment of three is shown; different animals or pools of animals were used for each experiment. $C, \beta$-tubulin was used as a loading control. $\boldsymbol{D}$, Green represents $\alpha 6$ integrin. Red represents neurofilament. Blue represents nuclei (DAPI). Of note, $\alpha 6$ integrin in mutant adult nerves is still present in blood vessels $\left({ }^{*}\right)$ and in the perineurium $\left(^{* *}\right)$, where POCre is not expressed. Scale bars: $A, 300 \mu \mathrm{m} ; \boldsymbol{D}, 35 \mu \mathrm{m}$.

source (Proxeon Biosystems). MS and MS/MS spectra were acquired selecting the 10 most intense ions per survey spectrum acquired in the orbitrap from $\mathrm{m} / \mathrm{z} 300-1750$ with 30,000 resolution. Target ions selected for the MS/MS were fragmented in the ion trap and dynamically excluded for $60 \mathrm{~s}$. For accurate mass measurements, the lock-mass option was used (Olsen et al., 2005). Peptides were identified from the MS/MS spectra searched against IPI MOUSE database (version 3.65) using Mascot 2.1 search engine. Cysteine carbamidomethylation was used as fixed modification, methionine oxidation, and protein $\mathrm{N}$-terminal acetylation as variable modifications. The initial mass tolerance in MS mode was set to $5 \mathrm{ppm}$ and MS/MS mass tolerance was $0.5 \mathrm{Da}$; a maximum of two missed cleavages was allowed. Peptides and proteins were accepted with two minimum peptides identified per protein one of which was unique.

Immunohistochemistry. Postnatal day 1, 5, and 28 sciatic nerves were dissected and either fixed in 4\% PFA for $30 \mathrm{~min}$ at room temperature or nonfixed, cryopreserved with $5 \%$ sucrose and $20 \%$ sucrose in PBS, embedded in OCT (Miles), and snap frozen in liquid nitrogen. Transverse or longitudinal $10-\mu \mathrm{m}$-thick sciatic nerve cryosections were permeabilized in cold acetone or methanol for $5 \mathrm{~min}$ and then blocked in 20\% FCS, $2 \%$ BSA, and $0.1 \%$ Triton $\mathrm{X}-100$ in PBS for $1 \mathrm{~h}$ at room temperature. Primary antibody incubation was done for $2 \mathrm{~h}$ at room temperature or $\mathrm{O} / \mathrm{N}$ at $4^{\circ} \mathrm{C}$ using antibodies diluted in blocking solution. Sections were then rinsed in PBS and incubated for $1 \mathrm{~h}$ with secondary antibodies, stained with DAPI, mounted with Vectashield (Vector Laboratories), and examined on a confocal microscope (PerkinElmer Ultraview).

Morphologic analysis. Mutant and control littermates were killed at the indicated ages, and sciatic nerves were dissected. Semithin section and electron microscopic analyses of sciatic nerves were performed as previously described (Wrabetz et al., 2006). Morphometric studies were performed on 17 random EM sections form $3 \alpha 6$ integrin mutant sciatic nerves and 3 controls, at a magnification of $1840 \times$. The fraction of hypomyelinated (g-ratio $>0.8$ ) or hypermyelinated fibers (g-ratio $<0.6$ )/total number of fibers was calculated and expressed in percentage. Fibers with g-ratio of $0.69 \pm$ 0.031 were considered normal. The density of unsorted axons, of axons with caliber $<1 \mu \mathrm{m}$ that were myelinated, or of axons with caliber $>1 \mu \mathrm{m}$ that were not myelinated, was calculated as the number of axons per unit area.

TUNEL and proliferation assays. TUNEL was performed as described previously (Feltri et al., 2002). For proliferation assays, sections were permeabilized with $0.2 \%$ Triton $\mathrm{X}-100$, blocked with ADS buffer (10\% FCS, $0.1 \mathrm{~m}$ lysine, and $0.02 \%$ sodium azide in $0.1 \mathrm{M}$ PBS), and incubated with a rabbit anti-PH3 primary antibody (Millipore) as described previously (Berti et al., 2011). Nuclei were counterstained with DAPI and analyzed with a fluorescence microscope. For both techniques, three different mice per genotype and four different slides per animal were analyzed.

Laminin production and purification. $\mathrm{Hu}-$ man embryonic kidney cells (HEK293) stably expressing $\alpha 2, \beta 1$, and $\gamma 1$ laminin chains (laminin 211) or $\alpha 4, \beta 1$, and $\gamma 1$ laminin chains (laminin 411) were produced and cultured as described previously (McKee et al., 2007). Recombinant laminins were then purified from media on anti-HA (for the 211 protein) or anti-FLAG (for the 411 protein) matrices (Sigma) packed in a Bio-Rad column.

Laminin-binding assay. Schwann cell-DRG neuron explant cultures were generated as described above and maintained for $5 \mathrm{~d}$ in culture in NB medium. Recombinant laminins 211 and 411 were added to the cell culture medium at the final concentration of $20 \mu \mathrm{g} / \mathrm{ml}$. After $3 \mathrm{~h}$ at $37^{\circ} \mathrm{C}$, explants were rinsed three times in PBS, fixed in PFA 4\%, and immunostained as described above. To quantify the relative amount of fluorescence in different samples, we used ImageJ to measure the fluorescent 
signals coming from laminin staining and from DAPI, in 20 fields per genotype, in each of three experiments. The laminin signal was normalized to the signal from DAPI.

Antibodies. The following antibodies were used for Western blotting: goat anti- $\alpha 6$ integrin (Santa Cruz Biotechnology); rabbit anti- $\alpha 7$ integrin (a gift from Guido Tarone, Department of Genetics, Biology and Biochemistry, University of Torino, Molecular Biotechnology Center, Torino, Italy); rabbit anti- $\alpha 3$ integrin (a gift from Michael DiPersio, Center for Cell Biology and Cancer Research, Albany Medical College, Albany, New York); mouse anti- $\beta 1$ integrin (BD Biosciences); rabbit anti-p42/44 and phospho-p42/44 (Thr202/Tyr204); rabbit anti-AKT and phospho-AKT (Ser473); rabbit anti-FAK and phospho-FAK (Tyr397); rabbit anti-Src and phospho-Src (Tyr416) (all from Cell Signaling Technology); chicken anti-P0 (Aves Laboratories); and rabbit anti-calnexin, mouse anti- $\beta$ tubulin, and peroxidase-conjugated secondary antibodies (Sigma) were used. For immunohistochemistry: rat anti- $\alpha 6$ integrin $(\mathrm{GoH} 3$, a gift from Arnoud Sonnenberg, Division of Cell Biology, The Netherlands Cancer Institute); rabbit anti- $\alpha 7$ integrin (from Ulrike Mayer); rat anti- $\alpha 2$ laminin (Alexis); rabbit anti- $\alpha 4$ laminin (a gift from Lydia Sorokin, Institute of Physiological Chemistry and Pathobiochemistry, University of Münster, Münster, Germany); rabbit antiNeurofilament H (Millipore Bioscience Research Reagents); and rat anti-Neurofilament (TA-51) and rat anti-MBP (gifts from V. Lee, University of Pennsylvania, Philadelphia). Secondary antibodies: Dy Light 488 or 549-conjugated secondary antibody (Jackson ImmunoResearch Laboratories).

\section{Results}

\section{Deletion of $\alpha 6$ integrin in Schwann cells does not impair} axonal sorting

The most abundant laminin receptor present in Schwann cells during axonal sorting is $\alpha 6 \beta 1$ integrin (Previtali et al., 2003b). We therefore produced and characterized mice with a deletion of $\alpha 6$ integrin specifically in Schwann cells ( $\alpha 6 \mathrm{cKO}$ ), by crossing $\alpha 6$ floxed mice, in which the genomic regions coding for the transmembrane portion are flanked by two loxP sites (A. De Arcangelis et al., manuscript in preparation), with the Schwann cell-specific mPOTOTCre mice (from here on called P0Cre). P0Cre activates Cre expression in the Schwann cell lineage starting at embryonic day 13.5 (E13.5) (Feltri and Wrabetz, unpublished observation), with ablation of the target protein a few days later (Feltri et al., 2002). When crossed with ubiquitous CMV-Cre mice, $\alpha 6^{\mathrm{F} / \mathrm{F}}$ mice showed the expected perinatal lethality resulting from skin blistering (Georges-Labouesse et al., 1996) (Fig. 1A), showing that the floxed $\alpha 6$ allele is successfully recombined. In contrast, mice with Schwann cell-specific deletion of $\alpha 6$ integrin are viable and fertile. Genomic DNA extracted from mutant sciatic nerves at postnatal day 1 (P1, the earliest time tested) showed the expected $1000 \mathrm{bp}$ recombination band after amplification of the $\alpha 6$ integrin locus, and only in the presence of P0Cre. A nonrecombined band was also visible, which could derive from nonrecombined Schwann cells, fibroblasts, or axons (Fig. 1B). Western blot and immunohistochemistry on developing sciatic nerves showed that the level of $\alpha 6$ integrin protein was significantly reduced in mutant Schwann cells at P1 and P5 and completely absent in adult Schwann cells. $\alpha 6$ integrin was still present in perineurial and endothelial cells, as expected (Fig. 1D). To evaluate the effect of $\alpha 6$ integrin ablation on axonal sorting and myelination, we analyzed developing sciatic nerves by semithin sections. Mutant nerves showed normal morphology with no evidence of radial sorting delay at P5 or radial sorting arrest at P28 (Fig. 2). Because the arrest of radial sorting in laminin 211 mutants is most evident in spinal roots (Bradley and Jenkison, 1975), we also analyzed dorsal and ventral spinal roots, which showed no overt phenotype (Fig. 2). Other aspects of nerve development, including the number of myelinated fibers, the endoneurial extracellular matrix content, or the perineurium, were preserved. To exclude the possibility that the absence of a pathological phenotype was the result of low levels of residual $\alpha 6$ integrin protein in early development, we asked whether DRG explants from $\alpha 6$ ubiquitous null embryos ( $\alpha 6$ integrin $^{-1-}$, transmitted via the germline from $\alpha 6$ integrin $^{F / F}$ CMVCre) were able to proceed normally through radial sorting and myelinate in vitro. Similar DRG explants prepared from $\beta 1$ integrin $^{F / F}$ POcre mice showed significant impairment in myelination, likely resulting from the radial sorting arrest, even if $\beta 1$ integrin protein levels were only reduced in $50 \%$ of Schwann cells (Nodari et al., 2007). DRGs were explanted from $\alpha 6$ integrin $^{-1-}$ mice at E14.5, to bypass the perinatal letalithy, and cultured in myelinating conditions. Despite the complete absence of $\alpha 6$ integrin protein in $\alpha 6$-null explants (Fig. $3 A$ ), there were no differences in the number of myelin internodes and in the amount of Myelin Protein Zero synthesized in mutant versus wild-type explants (Fig. 3). These in vitro observations paralleled the in vivo data and showed that the absence of $\alpha 6$ integrin does not impede radial sorting and myelination.

\section{Absence of $\alpha 6$ integrin from Schwann cells causes minor ensheathment and myelin abnormalities}

Analysis of Schwann cell-specific $\alpha 6$ null nerves by electron microscopy at P28 revealed minor, but frequent, abnormalities in 

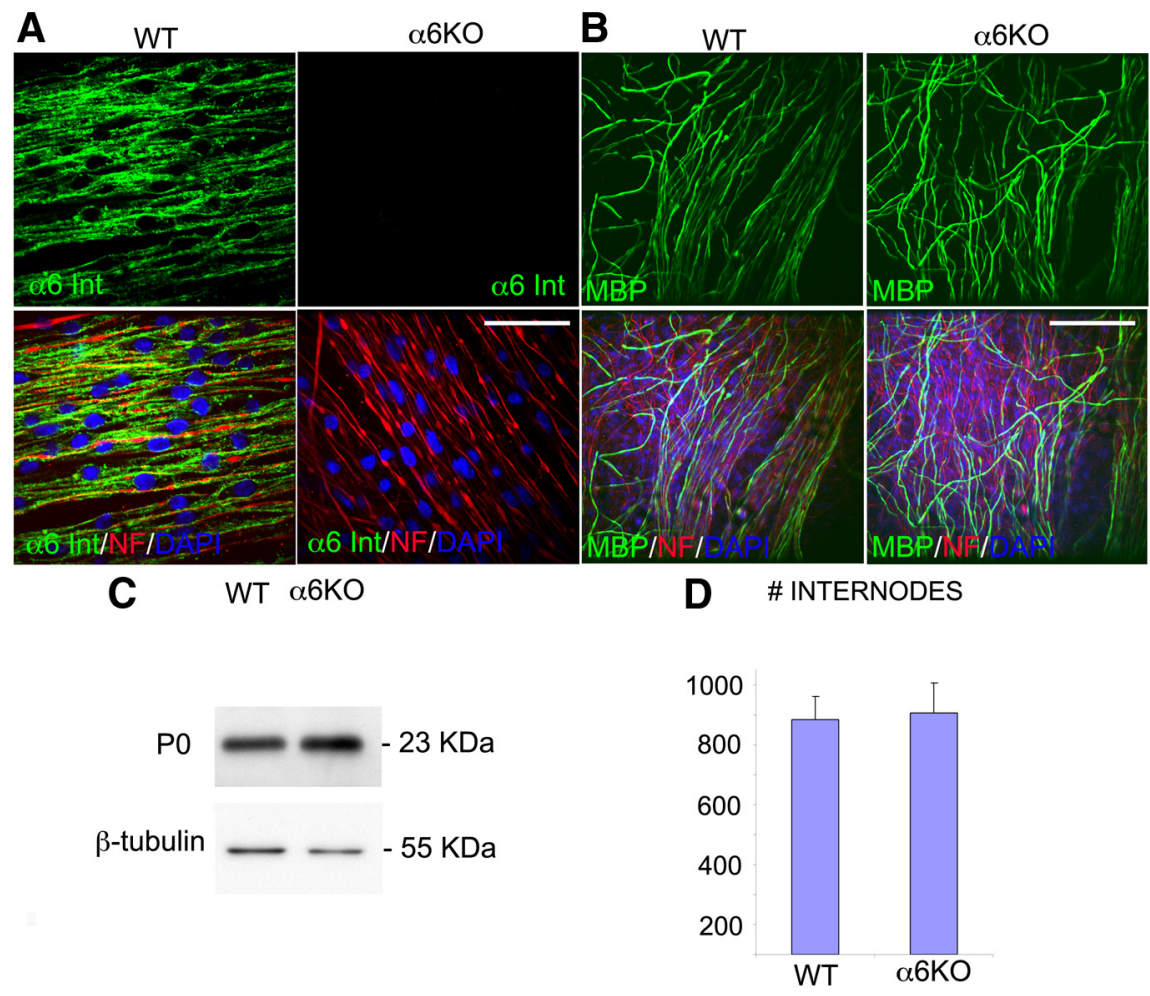

Figure 3. Absence of $\alpha 6$ integrin does not lead to radial sorting arrest and subsequent myelination defects in Schwann cell-DRG neuron explants. Schwann cell-DRG neuron explants were prepared from wild-type and $\alpha 6$ integrin constitutive null embryos, and induced to myelinate for $10 \mathrm{~d}$. $\boldsymbol{A}$, Wild-type and $\alpha 6$-deficient $(\alpha 6 \mathrm{~K} 0)$ explants were immunostained for $\alpha 6$ integrin (green), neurofilament (red), and nuclei (DAPI, blue); $\alpha 6$ protein is expressed in Schwann cells from wild-type explants, but it is absent in Schwann cells from deficient mice. $\boldsymbol{B}$, Wild-type and $\alpha 6$ integrin-null explants were immunostained for MBP (green), neurofilament (red), and nuclei (DAPI, blue). Both wild-type and $\alpha 6$ integrin-null Schwann cells can myelinate axons to a similar extent. One representative of three experiments is shown. $\boldsymbol{C}$, Western blot analysis of total protein extracts from wild-type and $\alpha 6$ integrin mutant explants shows a similar amount of $\mathrm{P} 0$ protein in null samples and controls. $\beta$-tubulin was used as a loading control. One representative of three experiments is shown. $\boldsymbol{D}$, Quantification of myelin internodes in wild-type and $\alpha 6$ integrin-null explants in three independent experiments; in each experiment, different pools of DRGs were used. The number of myelin segments is comparable between the two genotypes. Error bars indicate SEM. Statistical significance was measured by Student's $t$ test. Scale bars: $A, 35 \mu \mathrm{m} ; \boldsymbol{B}, 130 \mu \mathrm{m}$.

myelination. Remak bundles often contained abnormal axons that were $>1 \mu \mathrm{m}$ in diameter (Fig. $4 C, D$, asterisks), suggesting that they were not properly recognized as destined for myelination, or not sorted out of bundles. Other times, large-caliber axons were sorted by promyelinating Schwann cells, but not myelinated, suggesting a delay in myelination (Fig. $4 \mathrm{H}$, asterisks). In contrast, some axons $<1 \mu \mathrm{m}$ were abnormally myelinated (Fig. $4 E$, arrows, $F, G$, arrowheads), $25 \%$ of axons had overly thick (Fig. $4 A, B$, white arrowheads) and $5 \%$ overly thin (Fig. $4 C, F$, double asterisk) myelin for the caliber of the axon, and some fibers showed occasional axonal degeneration (Fig. 4I, J, arrows). These observations could reflect an impairment of $\alpha 6$ integrin-null Schwann cells to properly distinguish the threshold of $1 \mu \mathrm{m}$ above which an axon should be myelinated, and later also to regulate the proper amount of myelin for a given axonal caliber. Indeed, these alterations may indicate a deregulated radial sorting, suggesting a role for $\alpha 6$ integrin in this process. Overall, these data suggest that $\alpha 6$ integrin is important for axonal sorting and the formation of the correct amount of myelin, but its role may be redundant or compensated for by other molecules.

$\alpha 3$ Integrin is not required for radial sorting and myelination, and its role is not redundant with that of $\alpha 6$ integrin $\alpha 3 \beta 1, \alpha 6 \beta 1$, and $\alpha 7 \beta 1$ integrins could be redundant because they constitute a group of very similar integrins, which bind pref- erentially laminins and share structural characteristics, such as the absence of an $\alpha \mathrm{I}$-containing domain (for review, see Humphries et al., 2006). Previous studies showed that $\alpha 7 \beta 1$ integrin is not expressed at the time of radial sorting, and its deletion does not impair nerve development (Previtali et al., 2003a), whereas the role and expression of $\alpha 3 \beta 1$ integrin were never carefully assessed. Similarly, $\alpha 1 \beta 1$ and $\alpha 2 \beta 1$, other integrins that can bind laminin, but also collagen, are barely detectable by premyelinating Schwann cells in vivo (Stewart et al., 1997; Previtali et al., 2003a, 2003b). Collectively, these studies left the role of only one $\beta 1$ laminin-binding integrin unexplored, $\alpha 3 \beta 1$, suggesting that it may be redundant or compensating for $\alpha 6 \beta 1$ integrin during Schwann cell development. In addition, $\alpha 3 \beta 1$ and $\alpha 6 \beta 1$ integrins have redundant functions during formation of the ectodermal ridge and in organogenesis (De Arcangelis et al., 1999). By Western blot, we showed that $\alpha 3$ integrin is present in developing and mature sciatic nerves, but its expression is not increased when Schwann cells lack $\alpha 6 \beta 1$ integrin (Fig. $5 B$ ), suggesting lack of compensation, but not excluding redundancy. To investigate a possible role for $\alpha 3$ integrin in axonal sorting, we thus produced $\alpha 3$ conditional null mice $(\alpha 3 \mathrm{cKO})$ by crossing $\alpha 3$ integrin floxed (Liu et al., 2009) and P0Cre mice ( $\alpha 3^{F / F}$ P0Cre), and double $\alpha 3$ and $\alpha 6$ integrins mutant animals $\left(\alpha 3^{F / F} \alpha 6^{F / F}\right.$ P0Cre). Mutant animals showed absence of the $\alpha 3$ integrin protein in sciatic nerves by P28 (Fig. 5A). Semithin sections of single- and double-mutant sciatic nerves and spinal roots revealed a normal morphology: axons were normally sorted and myelinated (Fig. $5 C, D$ ). Therefore, $\alpha 3 \beta 1$ integrin is neither redundant nor compensatory for $\alpha 6 \beta 1$ integrin in sciatic nerves.

\section{$\alpha 7 \beta 1$ integrin compensates for $\alpha 6 \beta 1$ integrin in Schwann cells}

To ask by unbiased means which subunit partners with $\beta 1$ integrin in the absence of $\alpha 6$, we immunoprecipitated $\beta 1$ integrin from wild-type and mutant $\alpha 6$ integrin sciatic nerves at P5, a time when radial sorting is still ongoing, and identified its partners by mass spectrometry. The $\beta 1$ integrin subunit could be readily immunoprecipitated from both wild-type and mutant nerves (Fig. $6 A$ ), indicating that the overall amount of $\beta 1$ integrins was not reduced when $\alpha 6$ was deleted. Immunoprecipitates from mutant and wild-type nerves were separated on acrylamide gel, silver stained, and four areas containing bands of different intensity excised and analyzed by mass spectrometry. Interestingly, we found that $\beta 1$ integrin coimmunoprecipitated with $\alpha 7$ integrin only in $\alpha 6$ integrin mutant sciatic nerves, but not in wild-type nerve. The absence of $\alpha 7$ integrin wild-type nerves at P5 is in agreement with our previous report that most $\alpha 7$ integrin protein in Schwann cells is detected only after myelination, starting around P6, whereas in embryonic and perinatal nerves some $\alpha 7$ 

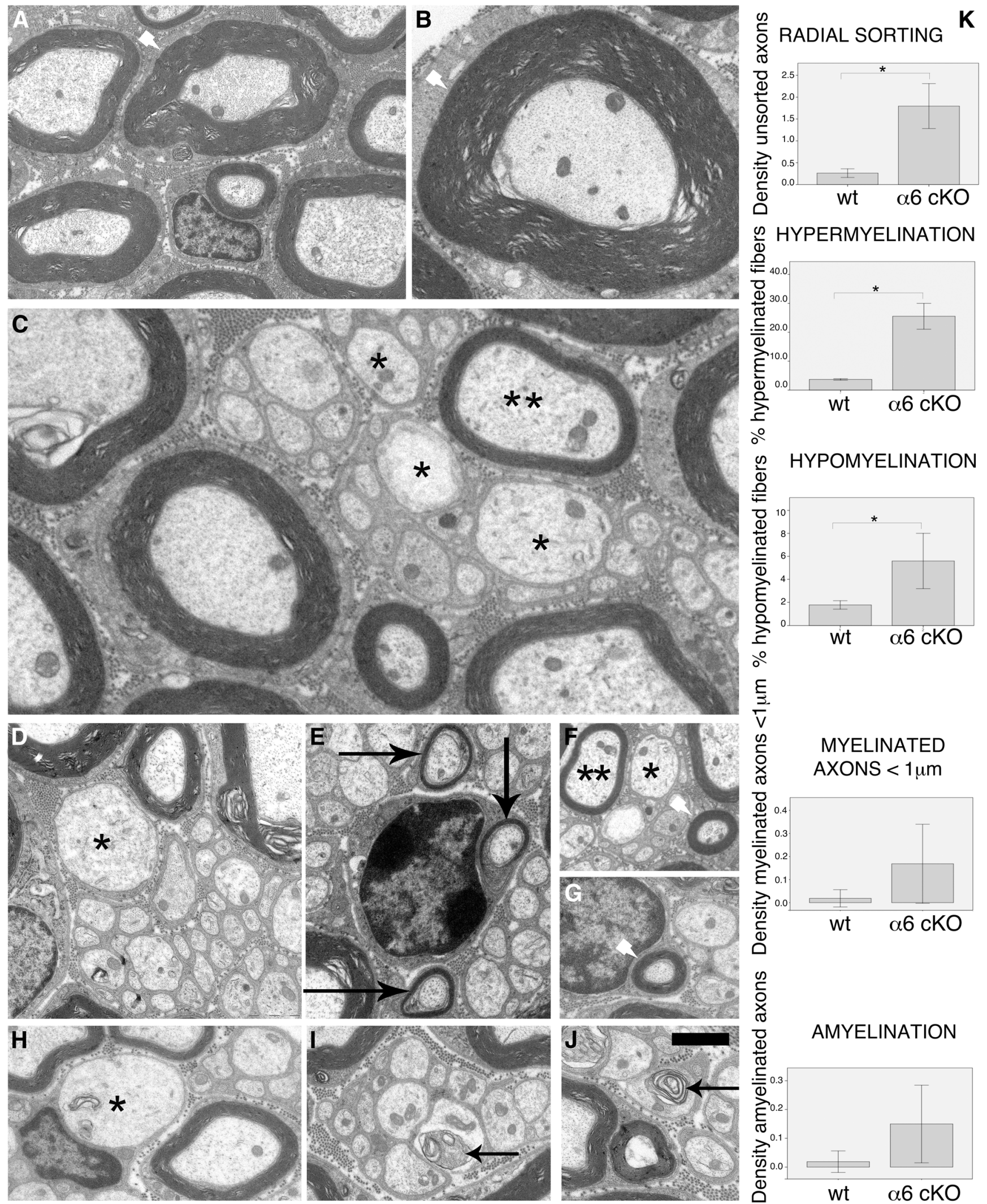

Figure 4. The absence of $\alpha 6$ integrin in Schwann cells causes ensheathment abnormalities in sciatic nerves. Electron microscopy analysis performed on $\alpha 6$ integrin ${ }^{F / F}$ POCre sciatic nerves at P28 revealed the presence of hypermyelination $\left(\boldsymbol{A}, \boldsymbol{B}\right.$, arrowheads), hypomyelination $\left(\boldsymbol{C}, \boldsymbol{F},{ }^{* *}\right)$, axons $<1 \mu \mathrm{m}$ inappropriately myelinated $(\boldsymbol{E}$, arrows), sometimes by a thick myelin sheath $(\boldsymbol{F}, \boldsymbol{G}$, arrowheads), Remak bundles containing axons $>1 \mu \mathrm{m}\left(\boldsymbol{C}, \boldsymbol{D}, \boldsymbol{F},{ }^{*}\right)$, axons $>1 \mu \mathrm{m}$ that were sorted but not myelinated $\left(\boldsymbol{H},{ }^{*}\right)$, and occasional signs of axonal degeneration $(\boldsymbol{I}, \boldsymbol{L}$, arrows). $\boldsymbol{K}$, Quantification of these abnormalities showed that $\sim 25 \%$ of fibers were hypermyelinated (g-ratio $<0.6$ ) and $\sim 5 \%$ of fibers were hypomyelinated ( $g$-ratio $>0.8$ ) in mutant nerves. Densities are indicated per $100 \mu \mathrm{m}^{2}$. Error bars indicate 2 SEs. ${ }^{*} p<0.05$ (Mann-Whitney test). Scale bars: $\boldsymbol{A}-\boldsymbol{C}, 2 \mu \mathrm{m} ; \boldsymbol{D}-\boldsymbol{K}, 1 \mu \mathrm{m}$. 
A
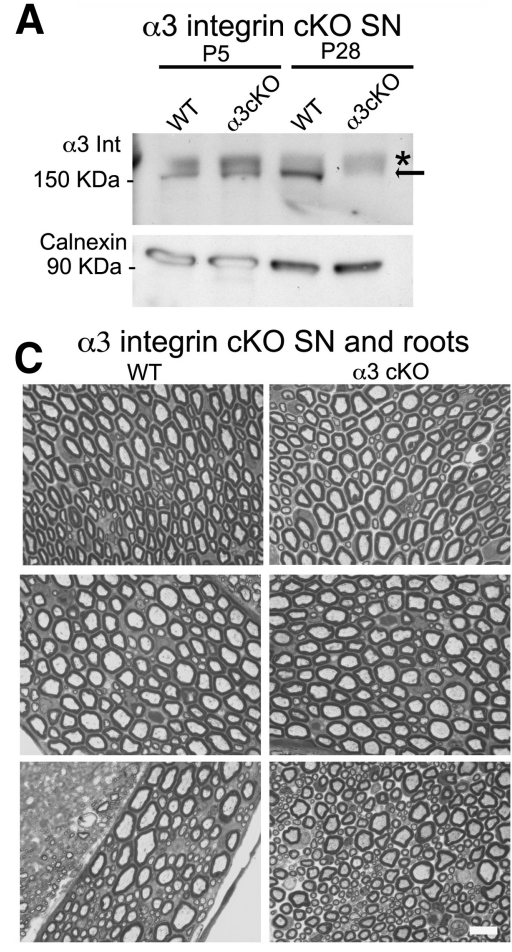

B

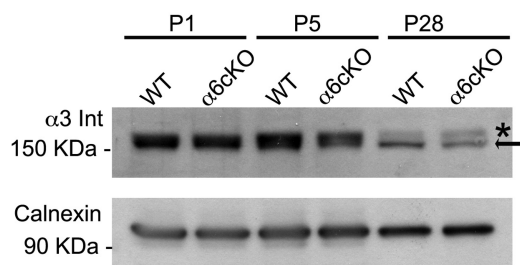

D

$\alpha 3 / \alpha 6$ integrin $\mathrm{cKO} S \mathrm{~N}$ and roots

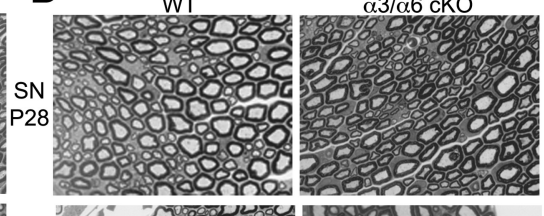
WT $\alpha 3 / \alpha 6$ cKO

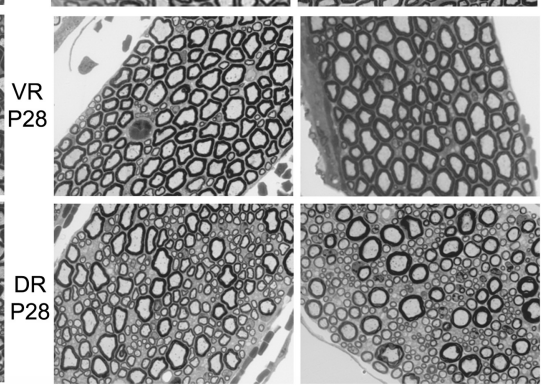

Figure 5. $\quad \alpha 3 \beta 1$ integrin is dispensable in peripheral nerve development and is neither redundant nor compensatory for $\alpha 6$ integrin. $\boldsymbol{A}$, Western blot analysis of total protein extracts from wild-type and $\alpha 3$ integrin ${ }^{F / F}$ POCre sciatic nerves shows that the $\alpha 3$ protein (arrow) is absent from mutant sciatic nerves at P28, but a residual level of the protein is still present in P5 mutant nerves. ${ }^{*}$ An aspecific band was detected in all samples. Calnexin was used as a loading control. Sciatic nerve pools from different animals were used for each sample. $\boldsymbol{B}$, Western blot analysis of total protein extracts from wild-type and $\alpha 6$ integrin ${ }^{\mathrm{F} / \mathrm{F}}$ POCre sciatic nerves shows that $\alpha 3$ integrin expression is comparable between wild-type and mutant sciatic nerves; thus, the absence of $\alpha 6$ integrin does not cause a compensatory upregulation of $\alpha 3$ integrin. Calnexin was used as a loading control. Sciatic nerve pools from different animals were used for each sample. C, D, Semithin sections of sciatic nerves (SN), dorsal (DR), and ventral roots (VR) from wild-type, $\alpha 3$, and double $\alpha 3 / \alpha 6$ integrin conditional null mice ( $\alpha 3$ integrin $^{F / F}, \alpha 6$ integrin $^{F / F} \mathrm{POC} r$ ) at P28. Single $\alpha 3$ and double $\alpha 3 / \alpha 6$ integrin mutant sciatic nerve and root morphology is comparable with control nerves. Scale bar, $10 \mu \mathrm{m}$.

integrin is expressed by axons (Previtali et al., 2003a). To validate that $\alpha 7$ integrin was expressed earlier in nerves in the absence of $\alpha 6$ integrin, we analyzed developing sciatic nerves from wild-type and $\alpha 6$ integrin mutant mice by Western blotting and immunohistochemistry. Strikingly, whereas $\alpha 7$ integrin was absent in the endoneurium and in Schwann cells at P1 and P5, mutant nerves showed significant amounts of $\alpha 7$ integrin in Schwann cells already at P1 (Fig. 6E). $\alpha 7$ integrin was not only expressed earlier but also significantly upregulated by Western blot analysis in mutant sciatic nerves at P1 and P5, during the time of radial sorting (Fig. 6B). Interestingly, this upregulation occurred at the post-translational level because $\alpha 7$ mRNA levels were comparable in mutant and wild-type nerves (Fig. 6D), and it was also detectable in $\alpha 6$ integrin-null explant cultures (Fig. 6C), indicating that the stimulus that triggers compensatory $\alpha 7$ expression was also present in the in vitro system that we used to assess myelination.

\section{Double $\alpha 6$ and $\alpha 7$ integrin mutants have radial sorting defects}

The upregulation of $\alpha 7$ integrin protein in $\alpha 6$ mutant sciatic nerves at the time of radial sorting prompted us to ablate both integrins in Schwann cells. We generated double $\alpha 6 / \alpha 7$ integrindeficient mice by crossing $\alpha 6$ integrin conditional-null mice and $\alpha 7$ null mice ( $\alpha 6^{F / F} \alpha 7^{-1-} \mathrm{P} 0 \mathrm{Cre}$ ). $\alpha 7$ integrin deficiency in mice causes a muscular dystrophy, with no peripheral neuropathy at the behavioral or morphological levels (Mayer et al., 1997; Previtali et al., 2003a). In contrast, morphological analysis of double $\alpha 6-\alpha 7$ integrin-deficient nerves revealed an arrest in radial sorting. Double-mutant sciatic nerves showed a delay in axonal sorting already apparent at P5 (Fig. 7D), and several bundles of naked axons, the hallmark of axonal sorting arrest, at P15 and P28 (arrows in Fig. 7D, H,L). Electron microscopy confirmed that the unsorted bundles of double $\alpha 6 / \alpha 7$ mutant nerves contained mixed caliber axons that were naked, without Schwann cell cytoplasm ensheathing them (Fig. $7 M, N$ ), and redundant and detached basal lamina, suggesting either the inability to anchor the basal lamina or the retraction of Schwann cell processes (Fig. 7O, arrows). These features are very similar to those observed in $\beta 1$ integrin conditional-null nerves (Feltri et al., 2002). Similar to single $\alpha 6$ integrin mutants, hypermyelinated axons and signs of axonal degeneration (Fig. $7 N, P$ ) were also observed.

\section{$\alpha 6$ - and $\alpha 7$-deficient Schwann cells} spread less when plated on laminin but can activate Racl

During radial sorting, Schwann cells must expand their surface area many-fold to extend cytoplasmic protrusions that contact and enwrap axons. The molecular mechanisms that mediate these dramatic cytoskeletal rearrangements are not completely understood, but similar to other cell types, the actin cytoskeleton plays an important role, as exemplified by the sorting and myelination defects resulting from deletion of Fak, ILK, Rac1, Cdc42, and N-Wasp in Schwann cells (Benninger et al., 2007; Grove et al., 2007; Nodari et al., 2007; Pereira et al., 2009; Jin et al., 2011; Novak et al., 2011). We previously showed that $\beta 1$ integrins are required for Schwann cell spreading, formation of lamellipodia, and activation of Rac1. To ask whether $\alpha 6$ or $\alpha 7$ integrins are also required in Schwann cells to expand their cytoplasm in response to laminin engagement, we analyzed the ability of $\alpha 6$ or $\alpha 7$ integrin-null Schwann cells to spread and activate Racl. Schwann cells were isolated from DRG neurons explants from $\alpha 6$ or $\alpha 7$ null embryos and plated on laminin 111-coated coverslips to induce cell spreading (Nodari et al., 2007). We found that both $\alpha 6$ and $\alpha 7$ null Schwann cells spread significantly less than wild-type cells when plated on laminin (Fig. 8A,B). However, pull-down of Rac1-GTP from P5 sciatic nerves did not reveal significant differences between the levels of active Rac1 in mutant nerves, except for a trend toward less activation in the absence of $\alpha 6$ and more activation in the absence of $\alpha 7$ integrin (Fig. 8C). Thus, either $\alpha 6$ or $\alpha 7$ integrins is required for Schwann cells to spread in response to laminin, which may explain the defect in radial sorting.

\section{All other major signaling pathways examined are activated normally in double-mutant nerves}

Several signaling pathways have been implicated in radial sorting. $\beta 1$ integrin mutant nerves present early impairment in multiple pathways involved in Schwann cell survival, proliferation, and 
cytoskeletal rearrangements, such as PI3K/AKT, RhoA and RhoE, and Src (Nodari et al., 2007; Berti et al., 2011). Activation of AKT is defective at the time of sorting in both laminin and $\beta 1$ integrin mutants, but this is probably the consequence, rather than the cause, of defective axonal contact (Yu et al., 2005; Berti et al., 2011). Deletion of the integrin adaptors Fak and ILK causes a severe axonal sorting phenotype reminiscent of the one observed in laminin and $\beta 1$ integrin-null mice (Grove et al., 2007; Pereira et al., 2009). Finally, Src is important downstream of neuregulin and Shp2 phosphatase (Grossmann et al., 2009), and its phosphorylation is decreased in $\beta 1$ integrin-deficient Schwann cells (Berti et al., 2011). To ask whether $\alpha 6 \beta 1, \alpha 7 \beta 1$, or both are required for the activation of these signaling cascades, we measured the levels of phosphorylation of these proteins in sciatic nerves from mutant mice at P5, during axonal sorting. Surprisingly, we did not detect significant differences in the activation of any of these pathways in single- or double-mutants (Fig. $8 D-G$ ), suggesting either that the signal coming from normally myelinating Schwann cells in the nerve was masking a small difference or that other $\alpha$ integrins that dimerize with $\beta 1$ are responsible for activating these signaling pathways.

\section{Schwann cells proliferate and survive normally in the absence of $\alpha 6$ and $\alpha 7$ integrins}

Mice mutants for laminins, Cdc42, Fak, or $\beta 1$ integrin present a moderate decrease in Schwann cell proliferation and/or an increase in apoptosis rate (Yang et al., 2005; Yu et al., 2005; Benninger et al., 2007; Grove et al., 2007; Berti et al., 2011). For these mutants, the reduced proliferation and survival could be a consequence of the failure to contact axons and thus to access proliferative cues coming from neuregulins on axons (Berti et al., 2011). In turn, reduced Schwann cell proliferation with concomitantly increased apoptosis could combine to reduce the number of Schwann cells available to engage in a 1:1 relationship with axons, aggravating the failure in axonal sorting. To verify whether Schwann cells showed reduced proliferation and survival in double $\alpha 6 / \alpha 7$ integrin mutant nerves, we measured the rate of apoptotic and proliferating cells by TUNEL and anti-phospho-histone 3 staining. As shown in Figure $8 H, I$, no significant differences in Schwann cell proliferation or apoptosis could be detected among the four genotypes analyzed, apart from an increase in proliferation of $\alpha 7$ integrin-null Schwann cells. These data indicate that the sorting defects observed in double $\alpha 6 / \alpha 7$ integrin mutant nerves are not caused by an insufficient number of Schwann cells to match axons.
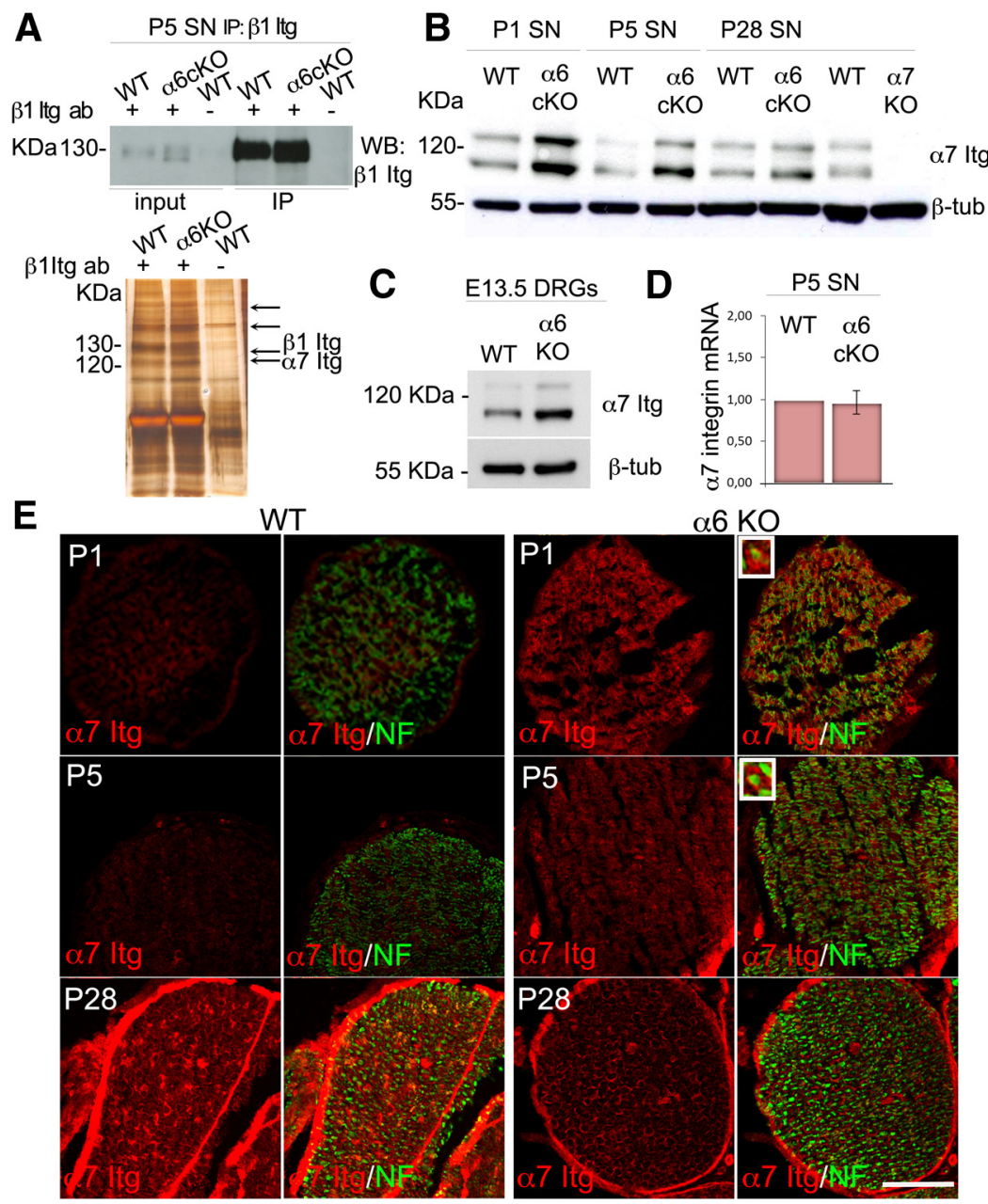

Figure 6. $\alpha 7$ integrin protein is expressed earlier and upregulated in sciatic nerves from $\alpha 6$ conditional null mice during development. $\boldsymbol{A}$, Top, Immunoprecipitation of $\beta 1$ integrin from wild-type and $\alpha 6$ conditional-null sciatic nerves at P5; blotting with $\beta 1$ integrin antibody shows similar amounts of $\beta 1$ integrin in wild-type and mutant sciatic nerves (SN) and significant enrichment compared with inputs (first two lanes). Omission of the primary antibody on wild-type samples was used as a negative control. Bottom, Mass spectrometry analysis was performed on four bands identified on the silver-stained immunoprecipitates (arrows). $\alpha 7$ was identified by mass spectrometry only in $\alpha 6$ mutant samples. $B, C$, Western blot analysis of total protein lysates from wild-type and mutant sciatic nerves $(\boldsymbol{B})$ or DRG explants $(\boldsymbol{C})$ validates a strong upregulation of $\alpha 7$ integrin when $\alpha 6$ integrin is absent in vivo and in vitro. $\alpha 6 \mathrm{KK} 0$, Schwann cell conditional knockout in $\boldsymbol{B} ; \alpha 6 \mathrm{KO}$, general knockout in $\boldsymbol{C} . \boldsymbol{B}, \alpha 7$ integrindeficient sciatic nerve lysate ( $\alpha 7 \mathrm{~K} 0$ ) was used as negative control for $\alpha 7$ integrin. One representative experiment of three is shown; nerves (or DRGS) were pooled from different animals in each experiment. $\boldsymbol{D}$, RNA extraction was performed on P5 wild-type and mutant sciatic nerves; and $\alpha 7$ integrin mRNA levels were assessed by real-time PCR. Error bars indicate SEM. The experiment was done in triplicate; nerves were pooled from different animals in each experiment. $\boldsymbol{E}$, Frozen sections of wild-type and $\alpha 6$ mutant sciatic nerves at P1, P5, and P28 immunostained for $\alpha 7$ integrin (red) and neurofilament (green). $\alpha 7$ integrin is expressed in Schwann cells only after myelination in WT nerves, but beginning at P1 in $\alpha 6$ integrin-null nerves. Magnified insets, Endoneurial $\alpha 7$ integrin staining comes from Schwann cells. Scale bar, $35 \mu \mathrm{m}$.

Absence of $\alpha 6$ or $\alpha 7$ integrin in Schwann cells decreases the binding of specific laminin isoforms

Laminins 211 and 411 are both required for axonal sorting, and genetic evidence suggests that they may have additive functions in Schwann cells because compound heterozygous nulls for laminins 211 and 411 ( $\operatorname{Lam} \alpha 4^{-/+} \mathrm{D} y^{2 J /+}$ mice) are normal (Yang et al., 2005), whereas ablation of either laminin $\alpha 2$ or $\alpha 4$ produces partial defects in radial sorting, and ablation of both laminins completely prevents the process (Yang et al., 2005; Yu et al., 2005). It has been proposed that this relates to the function of specific laminin-integrin pairs in Schwann cells because $\alpha 6 \beta 1$ integrin is required for adhesion to laminin 411 (Yang et al., 2005), whereas $\alpha 7 \beta 1$ integrin is a specific receptor for laminin 211 (Chernousov et al., 2007). However, the degree of specificity 

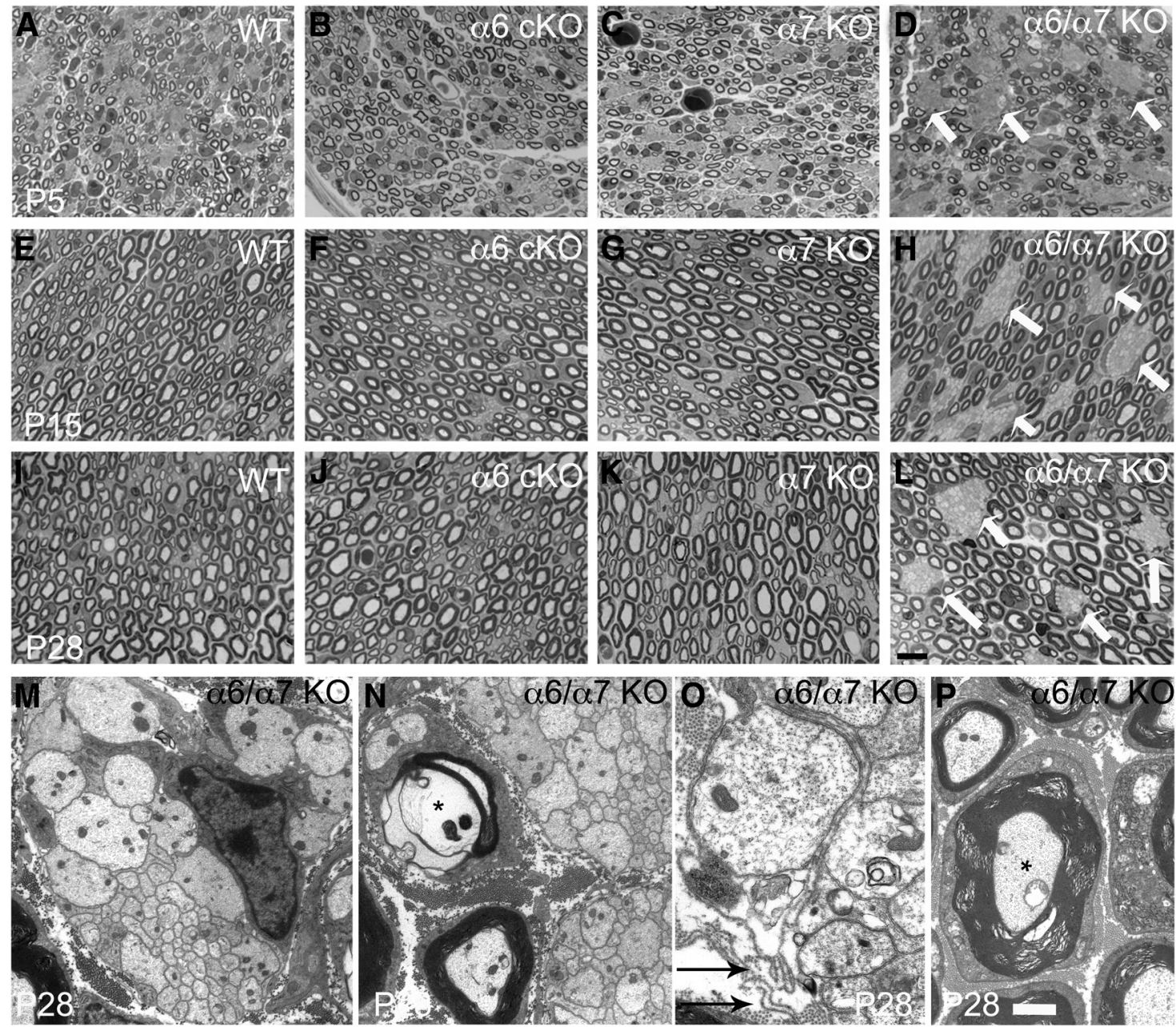

Figure 7. Double $\alpha 6 / \alpha 7$ mutant sciatic nerves have defective radial sorting throughout development. $A-L$, Semithin sections from wild-type, $\alpha 6$ integrin $S$ chwann cell conditional null nerves ( $\alpha 6 \mathrm{CK} 0), \alpha 7$ integrin-null nerves $(\alpha 7 \mathrm{~K} 0)$, and double $\alpha 6 / \alpha 7$ integrin mutant nerves $(\alpha 6 / \alpha 7 \mathrm{~K} 0)$ at P5, P15, and P28. In contrast to the normal morphology of single-mutant nerves, double-mutant sciatic nerves present many bundles of naked axons $(\boldsymbol{D}, \boldsymbol{H}, \boldsymbol{L}$, arrows), evidence of defective radial sorting. Scale bar, $10 \mu \mathrm{m}$. $\boldsymbol{B}$, Electron microscopy analysis of double $\alpha 6 / \alpha 7$ mutant sciatic nerves at $\mathbf{P} 28$ reveals the presence of bundles of naked and unsorted axons of mixed caliber $(\boldsymbol{M}, \boldsymbol{N})$, basal lamina detachment $\left(\boldsymbol{O}\right.$, arrows), hypermyelinated axons $\left(\boldsymbol{P},{ }^{*}\right)$, and occasional axonal degeneration $\left(\boldsymbol{N},{ }^{*}\right)$. Scale bars: $\boldsymbol{M}, \boldsymbol{N}, \boldsymbol{P}, 2 \mu \mathrm{m} ; \mathbf{0}, 1 \mu \mathrm{m}$.

between individual laminins and integrins is a matter of debate. When the affinity of laminins for soluble integrins is measured in a recombinant in vitro system, all integrins show promiscuous binding, and laminin 411 binds poorly to both receptors (Nishiuchi et al., 2006). In addition, laminin 411 was not able to promote myelination in DRG explants, which required instead high concentrations of laminin 211, with an intact polymerization and integrin binding domain (McKee et al., 2012). To address whether laminins 211 and 411 have preferential affinity for $\alpha 6 \beta 1$ or $\alpha 7 \beta 1$ integrins in Schwann cells, we took advantage of mutant DRG explant cultures that contain Schwann cells in contact with axons, a prerequisite for basal lamina synthesis and differentiation (for review, see Bunge et al., 1986), and a tridimensional orientation closer to the in vivo situation. Before the addition of ascorbic acid to induce myelination, these cells have an exposed basal surface that can be used to probe the binding of recombinant laminins. DRGs were explanted from embryos deficient in $\alpha 6$ or $\alpha 7$ integrins and used within $5 \mathrm{~d}$, a time in which only low levels of endogenous laminins were detected (Fig. 9). Next, we added recombinant laminin 211 or 411 , and after several washes we revealed the amount and organization of laminins bound to the Schwann cell surface, using antibodies specific to the $\alpha 2$ and $\alpha 4$ laminin chains. After addition of recombinant laminins, a network of polymerized laminin was evident on the surface of Schwann cells in wild-type explants, similar to what was described on cultured myotube cells (Colognato et al., 1999; Li et al., 2005). Interestingly, $\alpha 7$ integrin-deficient Schwann cells assembled a less prominent 211 laminin network, and $\alpha 6$ integrindeficient Schwann cells assembled a less evident 411 network. Of note, the organization of 411 laminin on the surface of $\alpha 6$ null Schwann cells also seemed more disordered compared with controls. These data support the idea that specific laminins may preferentially bind specific integrins on Schwann cells.

\section{Discussion}

In this paper, we identify the integrin receptors involved in radial sorting. We had previously shown that integrins of the $\beta 1$ class were essential for radial sorting of axons; however, which of the 11 possible $\alpha$ integrins dimerizes with $\beta 1$ to form the functional receptor was unknown. Here we show that $\alpha 6 \beta 1$ integrin is the receptor required, but its function in vivo can be compensated by $\alpha 7 \beta 1$ integrin. $\alpha 6 \beta 1$ integrin is probably the receptor that mediates radial sorting in physiological conditions because it is highly expressed at the appropriate time, in contrast to $\alpha 7 \beta 1$ integrin, 
A

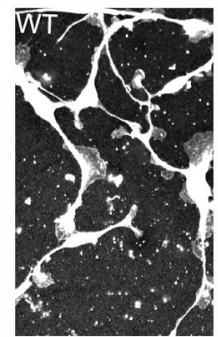

D
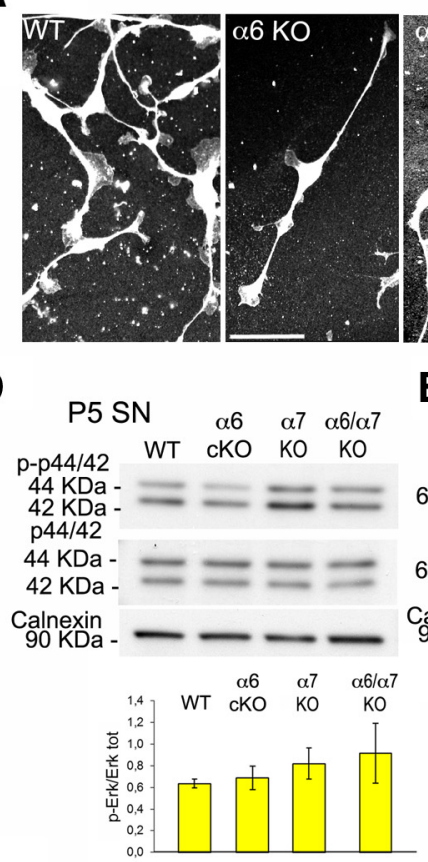

E

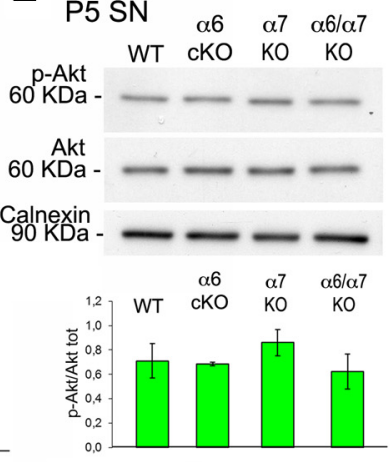

B

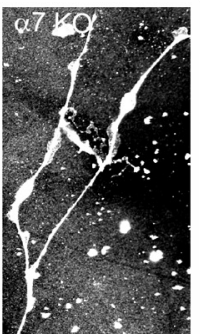

C

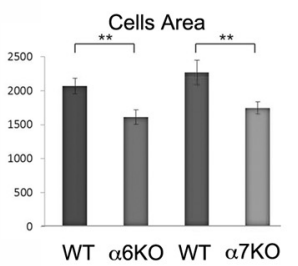

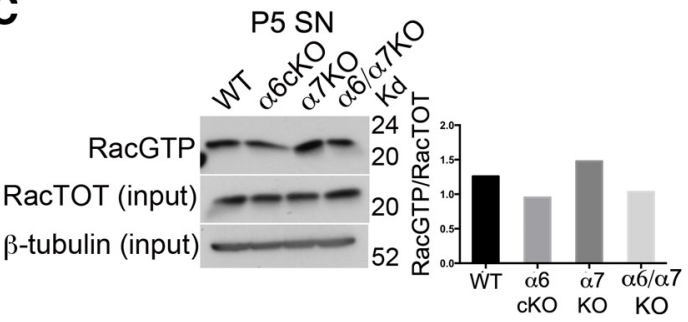

G

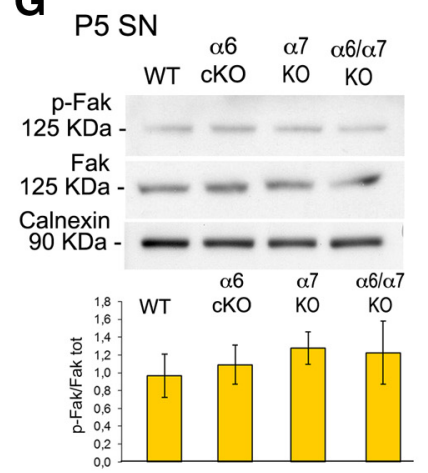

H

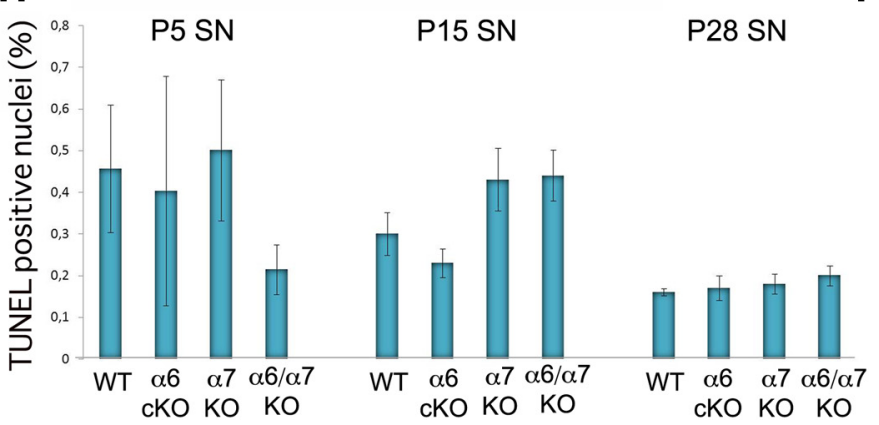

$\mathbf{F}$

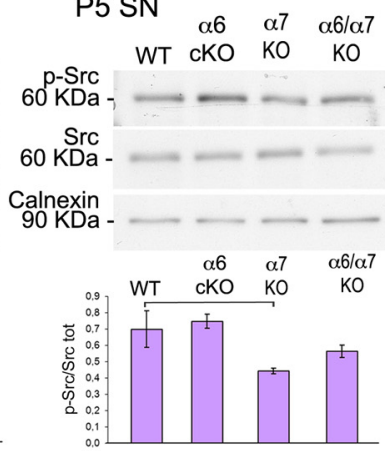

I

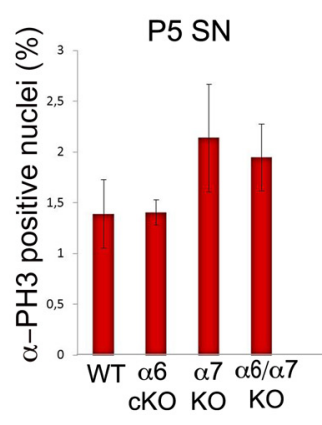

P28 SN

Figure 8. Double $\alpha 6 / \alpha 7$ mutant sciatic nerves do not show significant alterations in signaling, proliferation, and survival at the time of axonal sorting. $\boldsymbol{A}, \boldsymbol{B}$, Schwann cells from $\alpha 6$ and $\alpha 7$ integrin-null mice were isolated from DRG explant cultures, plated on laminin 111, and stained for $\$ 100$. Schwann cells area was measured by ImageJ software: both $\alpha 6$ and $\alpha 7$ null $\$$ chwann cells spread significantly less than wild-type cells on laminin. ${ }^{* *} p<0.01$ (Student's t test). C, Pull-down assay of Pak-binding-domain GST for Rac1 was performed on pools of $6-10$ P5 sciatic nerves from WT and mutant mice. Active proteins were normalized to total Rac1, and equal loading was verified by $\beta$-tubulin. One of two experiments is shown. $\boldsymbol{D}$ - $\mathbf{G}$, Western blot analysis on total protein extracts from three pools of 10-16 P5 sciatic nerves from mice of the indicated genotype reveals no significant alterations in the phosphorylation levels of ERK (D), AKT (Ser473) (E), Src (Tyr416) $(\boldsymbol{F})$, and Fak (Tyr397) (G) in double-mutants compared with controls. Calnexin was used as a loading control. One representative experiment of three is shown. Error bars indicate SEM. The statistical significance of the various replicates was measured by Student's t test. $\boldsymbol{H}, \boldsymbol{I}$, Frozen sections of mutant sciatic nerves at P5, P15, and P28 were analyzed by TUNEL or immunostained for phosphorylated histone3 (P-H3). The percentage of P-H3 $(\boldsymbol{H})$ or TUNEL $(\boldsymbol{G})$ positive nuclei was calculated for each genotype. No differences in the level of Schwann cell apoptosis or proliferation were observed, except for an increase in Schwann cell proliferation at P15 in $\alpha 7$ null and double $\alpha 6 / \alpha 7$ null nerves. Experiments were performed in triplicate; different pools of animals for each experiment were used. Error bars indicate SEM. ${ }^{*} p<0.05$ (Student's $t$ test).

which is normally not present in early Schwann cell development (Previtali et al., 2003a). In addition, only deletion of $\alpha 6$ integrin causes abnormalities that, albeit minor, can be ascribed to the inability to correctly assign axons to the myelinated or nonmyelinated phenotype. These abnormalities include the presence of axons $>1 \mu \mathrm{m}$ in Remak bundles, or conversely the inappropriate deposition of thick myelin sheaths around axons $<1 \mu \mathrm{m}$. In oligodendrocytes, $\beta 1$ integrins are thought to contribute to the recognition of the axonal threshold for myelination because mice expressing dominant-negative $\beta 1$ integrins require slightly larger axons than normal to become myelinated (Câmara et al., 2009). Similarly, it appears that, in the absence of $\alpha 6 \beta 1$ integrin, Schwann cells are more prone to misjudge the size of axons near the threshold for myelination. Thus, $\alpha 6 \beta 1$ integrins may act as molecular caliber in myelinating glia that properly "read" the size of axons, and in Schwann cells sort the ones to be myelinated. The molecular mechanisms are unknown but may be related to the ability of integrins to probe mechanical forces and constraints related to axonal size (for review, see Schiller and Fassler, 2013), or may be mediated by the amounts of Neuregulin 1 type III on axons, which is the quantitative signal that triggers myelin fate in Schwann cells (Michailov et al., 2004; Taveggia et al., 2005).

$\alpha 6$ and $\alpha 7$ integrins have distinct functions in Schwann cells Ablation of either $\alpha 6 \beta 1$ or $\alpha 7 \beta 1$ integrin is not sufficient to show a radial sorting phenotype in vivo because $\alpha 7 \beta 1$ can compensate for the absence of $\alpha 6 \beta 1$ integrin. However, the deletion of either $\alpha 6 \beta 1$ or $\alpha 7 \beta 1$ integrin causes detectable abnormalities in Schwann cells in vitro, namely, decreased binding of laminin 211 or 411, and reduced ability to spread. These abnormalities probably explain the partial radial sorting arrest that is observed when both $\alpha$ integrins are deleted in vivo. One outstanding question is 

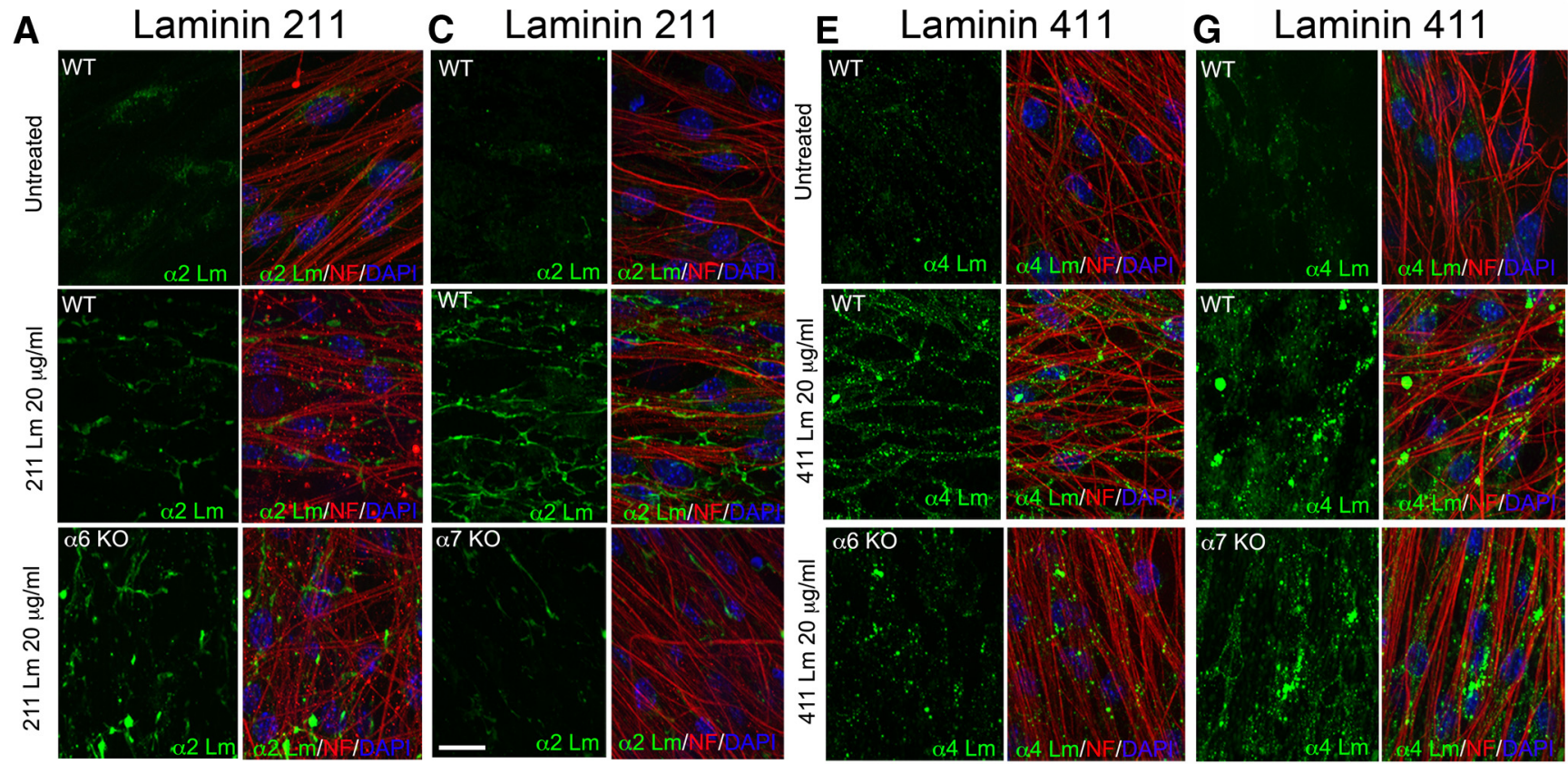

B

$\alpha 6 \mathrm{WT}+\mathrm{Lm} 211 \quad \alpha .6 \mathrm{KO}+\mathrm{Lm} 211$

D

$\alpha 7 W T+L m 211 \quad \alpha 7 K O+L m 211$
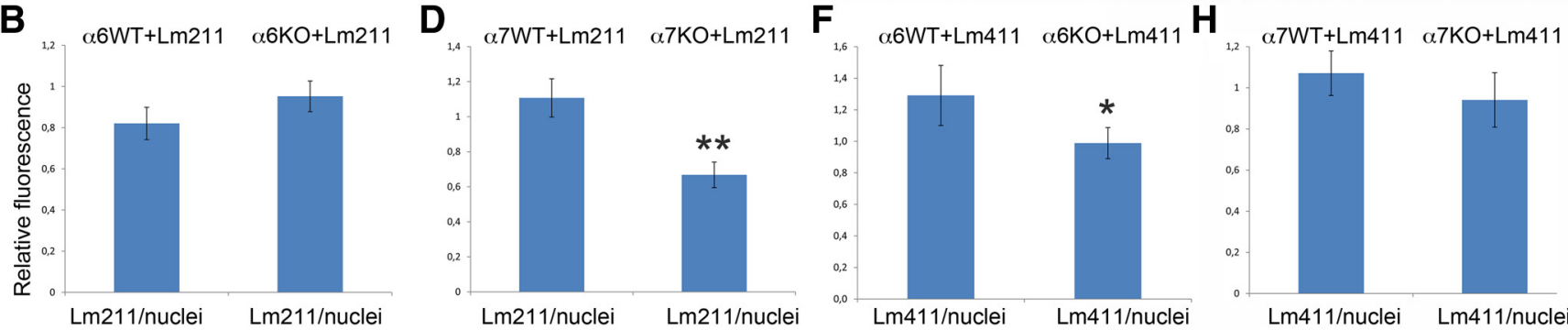

Figure 9. Deletion of $\alpha 6$ or $\alpha 7$ integrin in Schwann cells reduces binding to laminins 411 and 211 , respectively. DRG explant cultures from wild-type, $\alpha 6$ integrin $(\boldsymbol{A}, \boldsymbol{E})$, and $\alpha 7$ integrin $(\boldsymbol{C}, \boldsymbol{G})$ null embryos were cultured for $5 \mathrm{~d}$, then treated with laminin 211 or 411 at $37^{\circ} \mathrm{C}$ for $3 \mathrm{~h}$ to allow binding of laminins to the basal Schwann cell surface. After washing, cells were immunostained for $\alpha 2$ or $\alpha 4$ laminin chains (green), neurofilament (red), and DAPI (blue). Staining of untreated cells detected low levels of endogenous laminins. Laminin 211 binds less to $\alpha 7$ null explants, and laminin 411 binds less to $\alpha 6$ null samples. One representative experiment of three is shown. $\boldsymbol{B}, \boldsymbol{H}$, Semiquantitative estimation of the relative amount of fluorescence (green represents laminin; blue represents DAPI) in WT, $\alpha 6 \mathrm{KO}$, and $\alpha 7 \mathrm{~K} 0$ explants to which laminins were added was performed with ImageJ software. Scale bar, $15 \mu \mathrm{m}$. Error bars indicate SEM. ${ }^{*} p<0.05$ (Student's ttest). ${ }^{* *} p<$ 0.001 (Student's $t$ test).

why mammals have such an extensive repertoire of apparently partially redundant laminin isoforms and integrin receptors. One possibility is that a high density of laminin and integrin molecules is required for basal lamina assembly and function. This hypothesis is consistent with data showing that PNS myelination in vivo is particularly sensitive to laminin dosage (McKee et al., 2012) and in vitro high concentrations of laminins are necessary to polymerize and bind integrins required for myelination, whereas lower concentrations induce Schwann cell proliferation (Eldridge et al., 1989; McKee et al., 2012). Still, the fact that different laminins and integrin receptors are used suggests that some specificity exists in their function during radial sorting. Indeed, even if $\alpha 7$ integrin compensation is able to prevent an overt phenotype when $\alpha 6$ integrin is deleted, we showed that the absence of $\alpha 6 \beta 1$ reduces binding of laminin 411 , whereas the absence of $\alpha 7 \beta 1$ reduces binding of laminin 211 on Schwann cells. Of note, the reduced binding was evident despite the presence of dystroglycan, which binds laminin 211 with high affinity. This suggests a certain degree of ligand-receptor specificity in Schwann cells and is in agreement with previous data proposing that $\alpha 6 \beta 1$ and $\alpha 7 \beta 1$ integrin are preferred receptors for 411 and 211 laminin, respectively (Wallquist et al., 2005; Yang et al., 2005; Chernousov et al., 2007). Overall, these data suggest that, in physiological condi- tions, laminin 211/integrin $\alpha 7 \beta 1$ and laminin411/integrin $\alpha 6 \beta 1$ are preferred ligand-receptor pairs with specific functions in Schwann cells, but in pathological conditions one pair is able to substitute for the other to sort and myelinate axons.

\section{Radial sorting can be impaired, even if enough Schwann cells} are available to match the number of axons

Axonal sorting requires that Schwann cells can interact with axons and are in sufficient number to ensheath all axons. Interestingly, whereas $\alpha 6 \beta 1$ integrin is required for proper survival of oligodendrocyte precursors, $\alpha 6 \beta 1$ is dispensable for survival in Schwann cells. The survival of myelinating glia is regulated by axonal contact, which ensures the correct matching of the necessary number of glial cells in the CNS and peripheral nervous system (Barres et al., 1992; Grinspan et al., 1996; Trapp et al., 1997). Thus, decreased Schwann cell number is a possible reason for defect in axonal sorting, which is evident in mutants characterized by massive Schwann cell death, such as in transgenic mice expressing diphtheria toxin in Schwann cells, or deficient in Erb3 receptors (Messing et al., 1992; Riethmacher et al., 1997). In less extreme cases, when molecules that regulate both Schwann cell number and the cytoskeletal rearrangements required to interact and enwrap axons are deleted, both of these factors contribute to 
defects in radial sorting. This is the case for laminins, Cdc42, Fak, and $\beta 1$ integrin mutants in C57BL/6 background (Yang et al., 2005; Yu et al., 2005; Benninger et al., 2007; Grove et al., 2007; Berti et al., 2011) that show a moderate decrease in Schwann cell proliferation and a moderate increase in apoptosis. Even if subtle, a reduced proliferation with concomitantly increased apoptosis could contribute to diminish the number of cells available for axon ensheathment.

Many cases have also been described where radial sorting is partially or completely arrested, even in the presence of normal or excess Schwann cells, which are, however, incapable of interacting with axons. This is the case of $\beta 1$ integrin mutants in mixed C57BL/6//129 background, Racl, ILK, or N-WASP mutants (Benninger et al., 2007; Nodari et al., 2007; Pereira et al., 2009; Jin et al., 2011; Novak et al., 2011; Guo et al., 2012), and the $\alpha 6 / \alpha 7$ integrin-null mice described here. Similarly, in zebrafish, the role of ErbB2 in regulating process extension during radial sorting can be separated by its proliferative effect (Raphael et al., 2011). Thus, control of Schwann cell cytoskeleton and number are independently required for radial sorting of axons.

\section{Deletion of $\alpha 6$ and $\alpha 7$ integrins causes only a subset of the abnormalities caused by deletion of all $\beta 1$ integrins}

Even if $\alpha 6 / \alpha 7$ integrin double-mutants manifest a clear radial sorting phenotype, it is less severe than the phenotype obtained with deletion of all $\beta 1$ integrins (Feltri et al., 2002; Berti et al., 2011), and Schwann cells in the double-mutants show significantly less impairment of signaling. Several possibilities may explain this. The first is technical because a small residue of $\alpha 6$ is still present during early phases of postnatal development. This is surprising given the early activation of the P0Cre gene (E13.5) and is specific to $\alpha$ integrins, as it was never seen with any of the many proteins previously conditionally deleted in Schwann cells using P0Cre. The reason for this is unknown but may be related to a longer half-life of $\alpha$ integrins in Schwann cells. We do not believe that this explains the mild phenotype because complete absence of $\alpha 6$ integrin in vitro, a model usually more permissive to reveal a phenotype, did not impair radial sorting and myelination. Interestingly, the absence of $\alpha 6$ integrin in vitro and the significant down- regulation of $\alpha 6$ integrin in early development in vivo were both sufficient to induce earlier expression of $\alpha 7$ integrin. This indirectly shows that the decrease of $\alpha 6$ integrin was "sensed" by developing Schwann cells, which compensated by increasing expression of $\alpha 7$ integrin. Interestingly, $\alpha 7$ integrin can also compensate for members of the dystroglycan-dystrophin complex in human or mouse muscles (Hodges et al., 1997; Côté et al., 2002; Allikian et al., 2004), but in these cases $\alpha 7$ integrin is upregulated at the mRNA level. In contrast, we observe a post-translational increase in $\alpha 7$ integrin protein expression, which is, to our knowledge, unique among integrins.

We postulate instead that the function of $\alpha 6$ and $\alpha 7$ integrin might be compensated by non-laminin-binding $\beta 1$ integrins. The $\beta 1$ integrin subunit can interact with other $9 \alpha$ chains $(\alpha 1$, $\alpha 2, \alpha 4, \alpha 5, \alpha 8, \alpha 9, \alpha 10, \alpha 11$, and $\alpha \mathrm{V})$, many of which are expressed by Schwann cells (Lefcort et al., 1992; Milner et al., 1997; Stewart et al., 1997; Previtali et al., 2003b) and bind collagen, fibronectin, vitronectin, or cellular ligands. Conditional deletion of the fibronectin receptor $\alpha 5 \beta 1$ does not cause radial sorting abnormalities (M.P. and M.L.F., unpublished observations). However, it is possible that a collagen-binding integrin $(\alpha 1, \alpha 2$, $\alpha 10$, or $\alpha 11$ ) is compensating or redundant because deficiency of collagen XV aggravates the radial sorting phenotype due to laminin 411 deficiency (Rasi et al., 2010). Alternatively, we re- cently reported that, in early development, $\beta 1$ integrins are located also near axons by immune-electron microscopy (Berti et al., 2011); so we could speculate that a subset of $\alpha \beta 1$ integrins act independently of laminins and may directly interact with axons at the adaxonal surface. Despite the milder phenotype, our data conclusively show that $\alpha 6$ and $\alpha 7$ are the laminin integrins required for radial sorting of axons.

\section{References}

Allikian MJ, Hack AA, Mewborn S, Mayer U, McNally EM (2004) Genetic compensation for sarcoglycan loss by integrin alpha7betal in muscle. J Cell Sci 117:3821-3830. CrossRef Medline

Barres BA, Hart IK, Coles HS, Burne JF, Voyvodic JT, Richardson WD, Raff MC (1992) Cell death and control of cell survival in the oligodendrocyte lineage. Cell 70:31-46. CrossRef Medline

Benninger Y, Thurnherr T, Pereira JA, Krause S, Wu X, Chrostek-Grashoff A, Herzog D, Nave KA, Franklin RJ, Meijer D, Brakebusch C, Suter U, Relvas JB (2007) Essential and distinct roles for cdc42 and racl in the regulation of Schwann cell biology during peripheral nervous system development. J Cell Biol 177:1051-1061. CrossRef Medline

Berti C, Bartesaghi L, Ghidinelli M, Zambroni D, Figlia G, Chen ZL, Quattrini A, Wrabetz L, Feltri ML (2011) Non-redundant function of dystroglycan and betal integrins in radial sorting of axons. Development 138: 4025-4037. CrossRef Medline

Bradley WG, Jenkison M (1975) Neural abnormalities in the dystrophic mouse. J Neurol Sci 25:249-255. CrossRef Medline

Bunge RP, Bunge MB, Eldridge CF (1986) Linkage between axonal ensheathment and basal lamina production by Schwann cells. Annu Rev Neurosci 9:305-328. CrossRef Medline

Câmara J, Wang Z, Nunes-Fonseca C, Friedman HC, Grove M, Sherman DL, Komiyama NH, Grant SG, Brophy PJ, Peterson A, ffrench-Constant C (2009) Integrin-mediated axoglial interactions initiate myelination in the central nervous system. J Cell Biol 185:699-712. CrossRef Medline

Chernousov MA, Kaufman SJ, Stahl RC, Rothblum K, Carey DJ (2007) Alpha7betal integrin is a receptor for laminin-2 on Schwann cells. Glia 55:1134-1144. CrossRef Medline

Colognato H, Winkelmann DA, Yurchenco PD (1999) Laminin polymerization induces a receptor-cytoskeleton network. J Cell Biol 145:619-631. CrossRef Medline

Côté PD, Moukhles H, Carbonetto S (2002) Dystroglycan is not required for localization of dystrophin, syntrophin, and neuronal nitric-oxide synthase at the sarcolemma but regulates integrin alpha 7B expression and caveolin-3 distribution. J Biol Chem 277:4672-4679. CrossRef Medline

De Arcangelis A, Mark M, Kreidberg J, Sorokin L, Georges-Labouesse E (1999) Synergistic activities of alpha3 and alpha6 integrins are required during apical ectodermal ridge formation and organogenesis in the mouse. Development 126:3957-3968. Medline

Eldridge CF, Bunge MB, Bunge RP (1989) Differentiation of axon-related Schwann cells in vitro: II. Control of myelin formation by basal lamina. J Neurosci 9:625-638. Medline

Feltri ML, Wrabetz L (2005) Laminins and their receptors in Schwann cells and hereditary neuropathies. J Peripher Nerv Syst 10:128-143. CrossRef Medline

Feltri ML, D’Antonio M, Previtali S, Fasolini M, Messing A, Wrabetz L (1999) P0-Cre transgenic mice for inactivation of adhesion molecules in Schwann cells. Ann N Y Acad Sci 883:116-123. CrossRef Medline

Feltri ML, Graus Porta D, Previtali SC, Nodari A, Migliavacca B, Cassetti A, Littlewood-Evans A, Reichardt LF, Messing A, Quattrini A, Mueller U, Wrabetz L (2002) Conditional disruption of beta 1 integrin in Schwann cells impedes interactions with axons. J Cell Biol 156:199-209. CrossRef Medline

Georges-Labouesse E, Messaddeq N, Yehia G, Cadalbert L, Dierich A, Le Meur M (1996) Absence of integrin alpha 6 leads to epidermolysis bullosa and neonatal death in mice. Nat Genet 13:370-373. CrossRef Medline

Germain M, De Arcangelis A, Robinson SD, Baker M, Tavora B, D’Amico G, Silva R, Kostourou V, Reynolds LE, Watson A, Jones JL, GeorgesLabouesse E, Hodivala-Dilke K (2010) Genetic ablation of the alpha 6-integrin subunit in TielCre mice enhances tumour angiogenesis. J Pathol 220:370-381. CrossRef Medline

Grinspan JB, Marchionni MA, Reeves M, Coulaloglou M, Scherer SS (1996) 
Axonal interactions regulate Schwann cell apoptosis in developing peripheral nerve: neuregulin receptors and the role of neuregulins. J Neurosci 16:6107-6118. Medline

Grossmann KS, Wende H, Paul FE, Cheret C, Garratt AN, Zurborg S, Feinberg K, Besser D, Schulz H, Peles E, Selbach M, Birchmeier W, Birchmeier C (2009) The tyrosine phosphatase Shp2 (PTPN11) directs Neuregulin1/ErbB signaling throughout Schwann cell development. Proc Natl Acad Sci U S A 106:16704-16709. CrossRef Medline

Grove M, Komiyama NH, Nave KA, Grant SG, Sherman DL, Brophy PJ (2007) FAK is required for axonal sorting by Schwann cells. J Cell Biol 176:277-282. CrossRef Medline

Guo L, Moon C, Niehaus K, Zheng Y, Ratner N (2012) Racl controls Schwann cell myelination through cAMP and NF2/merlin. J Neurosci 32:17251-17261. CrossRef Medline

Helbling-Leclerc A, Zhang X, Topaloglu H, Cruaud C, Tesson F, Weissenbach J, Tomé FM, Schwartz K, Fardeau M, Tryggvason K (1995) Mutations in the laminin alpha 2-chain gene (LAMA2) cause merosin-deficient congenital muscular dystrophy. Nat Genet 11:216-218. CrossRef Medline

Hodges BL, Hayashi YK, Nonaka I, Wang W, Arahata K, Kaufman SJ (1997) Altered expression of the alpha7betal integrin in human and murine muscular dystrophies. J Cell Sci 110:2873-2881. Medline

Humphries JD, Byron A, Humphries MJ (2006) Integrin ligands at a glance. J Cell Sci 119:3901-3903. CrossRef Medline

Jin F, Dong B, Georgiou J, Jiang Q, Zhang J, Bharioke A, Qiu F, Lommel S, Feltri ML, Wrabetz L, Roder JC, Eyer J, Chen X, Peterson AC, Siminovitch KA (2011) N-WASp is required for Schwann cell cytoskeletal dynamics, normal myelin gene expression and peripheral nerve myelination. Development 138:1329-1337. CrossRef Medline

Lefcort F, Venstrom K, McDonald JA, Reichardt LF (1992) Regulation of expression of fibronectin and its receptor, alpha 5 beta 1, during development and regeneration of peripheral nerve. Development 116:767-782. Medline

Li S, Liquari P, McKee KK, Harrison D, Patel R, Lee S, Yurchenco PD (2005) Laminin-sulfatide binding initiates basement membrane assembly and enables receptor signaling in Schwann cells and fibroblasts. J Cell Biol 169:179-189. CrossRef Medline

Liu Y, Chattopadhyay N, Qin S, Szekeres C, Vasylyeva T, Mahoney ZX, Taglienti M, Bates CM, Chapman HA, Miner JH, Kreidberg JA (2009) Coordinate integrin and c-Met signaling regulate Wnt gene expression during epithelial morphogenesis. Development 136:843-853. CrossRef Medline

Mayer U, Saher G, Fässler R, Bornemann A, Echtermeyer F, von der Mark H, Miosge N, Pöschl E, von der Mark K (1997) Absence of integrin alpha 7 causes a novel form of muscular dystrophy. Nat Genet 17:318-323. CrossRef Medline

McKee KK, Harrison D, Capizzi S, Yurchenco PD (2007) Role of laminin terminal globular domains in basement membrane assembly. J Biol Chem 282:21437-21447. CrossRef Medline

McKee KK, Yang DH, Patel R, Chen ZL, Strickland S, Takagi J, Sekiguchi K, Yurchenco PD (2012) Schwann cell myelination requires integration of laminin activities. J Cell Sci 125:4609-4619. CrossRef Medline

Messing A, Behringer RR, Hammang JP, Palmiter RD, Brinster RL, Lemke G (1992) P0 promoter directs expression of reporter and toxin genes to Schwann cells of transgenic mice. Neuron 8:507-520. CrossRef Medline

Michailov GV, Sereda MW, Brinkmann BG, Fischer TM, Haug B, Birchmeier C, Role L, Lai C, Schwab MH, Nave KA (2004) Axonal neuregulin-1 regulates myelin sheath thickness. Science 304:700-703. CrossRef Medline

Milner R, Wilby M, Nishimura S, Boylen K, Edwards G, Fawcett J, Streuli C, Pytela R, ffrench-Constant C (1997) Division of labor of Schwann cell integrins during migration on peripheral nerve extracellular matrix ligands. Dev Biol 185:215-228. CrossRef Medline

Miner JH, Yurchenco PD (2004) Laminin functions in tissue morphogenesis. Annu Rev Cell Dev Biol 20:255-284. CrossRef Medline

Nishiuchi R, Takagi J, Hayashi M, Ido H, Yagi Y, Sanzen N, Tsuji T, Yamada M, Sekiguchi K (2006) Ligand-binding specificities of laminin-binding integrins: a comprehensive survey of laminin-integrin interactions using recombinant alpha3beta1, alpha6betal, alpha7betal and alpha6beta 4 integrins. Matrix Biol 25:189-197. CrossRef Medline

Nodari A, Zambroni D, Quattrini A, Court FA, D’Urso A, Recchia A, Tybulewicz VL, Wrabetz L, Feltri ML (2007) Betal integrin activates Rac1 in
Schwann cells to generate radial lamellae during axonal sorting and myelination. J Cell Biol 177:1063-1075. CrossRef Medline

Novak N, Bar V, Sabanay H, Frechter S, Jaegle M, Snapper SB, Meijer D, Peles E (2011) N-WASP is required for membrane wrapping and myelination by Schwann cells. J Cell Biol 192:243-250. CrossRef Medline

Occhi S, Zambroni D, Del Carro U, Amadio S, Sirkowski EE, Scherer SS, Campbell KP, Moore SA, Chen ZL, Strickland S, Di Muzio A, Uncini A, Wrabetz L, Feltri ML (2005) Both laminin and Schwann cell dystroglycan are necessary for proper clustering of sodium channels at nodes of Ranvier. J Neurosci 25:9418-9427. CrossRef Medline

Olsen JV, de Godoy LM, Li G, Macek B, Mortensen P, Pesch R, Makarov A, Lange O, Horning S, Mann M (2005) Parts per million mass accuracy on an Orbitrap mass spectrometer via lock mass injection into a C-trap. Mol Cell Proteomics 4:2010-2021. CrossRef Medline

Pereira JA, Benninger Y, Baumann R, Gonçalves AF, Ozçelik M, Thurnherr T, Tricaud N, Meijer D, Fässler R, Suter U, Relvas JB (2009) Integrinlinked kinase is required for radial sorting of axons and Schwann cell remyelination in the peripheral nervous system. J Cell Biol 185:147-161. CrossRef Medline

Previtali SC, Dina G, Nodari A, Fasolini M, Wrabetz L, Mayer U, Feltri ML, Quattrini A (2003a) Schwann cells synthesize alpha7betal integrin which is dispensable for peripheral nerve development and myelination. Mol Cell Neurosci 23:210-218. CrossRef Medline

Previtali SC, Nodari A, Taveggia C, Pardini C, Dina G, Villa A, Wrabetz L, Quattrini A, Feltri ML (2003b) Expression of laminin receptors in Schwann cell differentiation: evidence for distinct roles. J Neurosci 23: 5520-5530. Medline

Raphael AR, Lyons DA, Talbot WS (2011) ErbB signaling has a role in radial sorting independent of Schwann cell number. Glia 59:1047-1055. CrossRef Medline

Rasi K, Hurskainen M, Kallio M, Stavén S, Sormunen R, Heape AM, Avila RL, Kirschner D, Muona A, Tolonen U, Tanila H, Huhtala P, Soininen R, Pihlajaniemi T (2010) Lack of collagen XV impairs peripheral nerve maturation and, when combined with laminin-411 deficiency, leads to basement membrane abnormalities and sensorimotor dysfunction. J Neurosci 30:14490-14501. CrossRef Medline

Riethmacher D, Sonnenberg-Riethmacher E, Brinkmann V, Yamaai T, Lewin GR, Birchmeier C (1997) Severe neuropathies in mice with targeted mutations in the ErbB3 receptor. Nature 389:725-730. CrossRef Medline

Schiller HB, Fässler R (2013) Mechanosensitivity and compositional dynamics of cell-matrix adhesions. EMBO Rep 14:509-519. CrossRef Medline

Stewart HJ, Turner D, Jessen KR, Mirsky R (1997) Expression and regulation of alphalbetal integrin in Schwann cells. J Neurobiol 33:914-928. CrossRef Medline

Taveggia C, Zanazzi G, Petrylak A, Yano H, Rosenbluth J, Einheber S, Xu X, Esper RM, Loeb JA, Shrager P, Chao MV, Falls DL, Role L, Salzer JL (2005) Neuregulin-1 type III determines the ensheathment fate of axons. Neuron 47:681-694. CrossRef Medline

Trapp BD, Nishiyama A, Cheng D, Macklin W (1997) Differentiation and death of premyelinating oligodendrocytes in developing rodent brain. J Cell Biol 137:459-468. CrossRef Medline

Wallquist W, Plantman S, Thams S, Thyboll J, Kortesmaa J, Lännergren J, Domogatskaya A, Ogren SO, Risling M, Hammarberg H, Tryggvason K, Cullheim S (2005) Impeded interaction between Schwann cells and axons in the absence of laminin alpha4. J Neurosci 25:3692-3700. CrossRef Medline

Webster HD, Martin R, O'Connell MF (1973) The relationships between interphase Schwann cells and axons before myelination: a quantitative electron microscopic study. Dev Biol 32:401-416. CrossRef Medline

Wrabetz L, D’Antonio M, Pennuto M, Dati G, Tinelli E, Fratta P, Previtali S, Imperiale D, Zielasek J, Toyka K, Avila RL, Kirschner DA, Messing A, Feltri ML, Quattrini A (2006) Different intracellular pathomechanisms produce diverse Myelin Protein Zero neuropathies in transgenic mice. J Neurosci 26:2358-2368. CrossRef Medline

Yang D, Bierman J, Tarumi YS, Zhong YP, Rangwala R, Proctor TM, Miyagoe-Suzuki Y, Takeda S, Miner JH, Sherman LS, Gold BG, Patton BL (2005) Coordinate control of axon defasciculation and myelination by laminin-2 and -8. J Cell Biol 168:655-666. CrossRef Medline

Yu WM, Feltri ML, Wrabetz L, Strickland S, Chen ZL (2005) Schwann cellspecific ablation of laminin gammal causes apoptosis and prevents proliferation. J Neurosci 25:4463-4472. CrossRef Medline 